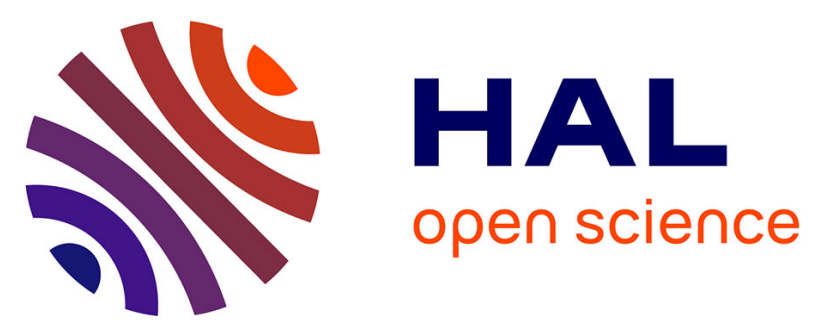

\title{
Facing up to the paradigm of ecological intensification in agronomy: Revisiting methods, concepts and knowledge
}

Thierry Doré, David Makowski, Eric Malézieux, Nathalie G. Munier-Jolain, Marc Tchamitchian, Pablo Tittonell

\section{- To cite this version:}

Thierry Doré, David Makowski, Eric Malézieux, Nathalie G. Munier-Jolain, Marc Tchamitchian, et al.. Facing up to the paradigm of ecological intensification in agronomy: Revisiting methods, concepts and knowledge. European Journal of Agronomy, 2011, 34 (4), pp.197-210. 10.1016/j.eja.2011.02.006 . hal-01355604

HAL Id: hal-01355604

https://hal-agroparistech.archives-ouvertes.fr/hal-01355604

Submitted on 23 Aug 2016

HAL is a multi-disciplinary open access archive for the deposit and dissemination of scientific research documents, whether they are published or not. The documents may come from teaching and research institutions in France or abroad, or from public or private research centers.
L'archive ouverte pluridisciplinaire HAL, est destinée au dépôt et à la diffusion de documents scientifiques de niveau recherche, publiés ou non, émanant des établissements d'enseignement et de recherche français ou étrangers, des laboratoires publics ou privés.

\section{(ㅇ)(1) $\$$}

Distributed under a Creative Commons Attribution - NonCommercial - NoDerivatives $\mid 4.0$ 
4 Facing up to the paradigm of ecological intensification in agronomy: revisiting methods, concepts and knowledge

6 Thierry Doré ${ }^{\mathrm{a}}$, David Makowski $^{\mathrm{b}}$, Eric Malézieux ${ }^{\mathrm{c}}$, Nathalie Munier-Jolain ${ }^{\mathrm{d}}$, Marc $7 \quad$ Tchamitchian $^{\mathrm{e}}$, Pablo Tittonell ${ }^{\mathrm{f}}$

$9 \quad{ }^{a}$ AgroParisTech, INRA, UMR 211, F-78850 Thiverval-Grignon, France

$10 \quad{ }^{\mathrm{b}}$ INRA, AgroParisTech, UMR 211, F-78850 Thiverval-Grignon, France

$11{ }^{\mathrm{c}}$ CIRAD, UR HortSys, Boulevard de la Lironde, TA B-103/PS4, 34398 Montpellier Cedex , 12 France

13 d INRA, UMR 102 Génétique et Ecophysiologie des Légumineuses, 17 rue Sully, BP 86510,

14 F-21065 Dijon Cedex, France

$15{ }^{\mathrm{e}}$ INRA,Unité Ecodéveloppement, Centre PACA, F-84914 Avignon Cedex 9, France

$16{ }^{\mathrm{f}}$ CIRAD-Persyst,Systèmes de Culture Annuels, TA B-102/02 Avenue Agropolis, 34898

17 Montpellier Cedex 5, France

18

19 Corresponding author: Thierry Doré

20 thierry.dore@agroparistech.fr

21 Phone (33) 130815245 Fax (33) 130815425

23 Key-words: agroecology, agroecosystem, plant science, farmers' knowledge, meta-analysis, 24 comparative analysis 
Agriculture is facing up to an increasing number ofchallenges, including the need to ensure variousecosystem services and to resolve apparent conflicts betweenthem. One of the ways forward for agriculture currently being debated is a set of principles grouped together under the umbrella term "ecological intensification".In published studies, ecological intensification has generally been considered to be based essentially on the use of biological regulation to manage agroecosystems, at field, farm and landscape scales. We propose here five additional avenues that agronomic research could follow to strengthen the ecological intensification of current farming systems. We begin by assuming that progress in plant sciencesover the last two decades provides new insight of potential use toagronomists. Potentially useful new developments in plant science include advances in the fields of energy conversion by plants, nitrogen use efficiency and defence mechanisms against pests. We then suggest that natural ecosystems may also provide sources of inspiration for cropping system design, in terms of theirstructure and function on the onehand, and farmers' knowledge on the other. Natural ecosystems display a number of interesting properties that could be incorporated into agroecosystems. Wediscuss the value and limitations of attempting to 'mimic' their structure and function, while considering the differences in objectives and constraints between these two types of system. Farmers develop extensive knowledge of the systems they manage. We discuss ways in which this knowledge could be combined with, or fed into scientific knowledge and innovation, and the extent to which this is likely to be possible. The two remaining avenues concern methods. We suggest that agronomists make more use of metaanalysis and comparative system studies, these two types of methods being commonly used in other disciplines but barely usedin agronomy. Meta-analysis would make it possible to quantify variations of cropping system performances in interaction with soil and climate 
51 analysis would help to identify the structural characteristics of cropping and farming systems

52 underlying properties of interest. Such analysis can be performedwith sets of performance 53 indicators andmethods borrowed from ecology for analyses of thestructure and organisation of 54 these systems. These five approaches should make it possible to deepen our knowledge of 55 agroecosystems for action.

56

57

58 


\section{Introduction}

61

New agricultural systems are required toallow agriculture to satisfy the increasingly diverseexpectations of society. For decades, agronomy has produced knowledge and designed agroecosystems for maximising the production of primary food and fibre, either for direct consumption orfor industrial use. Agricultural production issues have recently been expanded toinclude other ecosystem services (Zhang et al., 2007). Likeother natural and semi-artificial ecosystems, agroecosystems can provide services, such as carbon sequestration, pollination, or water filtration. The capacity of agriculture to providesuch services is, of course, not always guaranteed, and there are manyexamples of adverse effects of agricultural practiceson the environment, leading to ecological disservices of agriculture (Matson et al., 1997; Swinton et al., 2007). Disservices may include decreases in water and air quality or a contribution to biodiversity loss. As agroecosystems are ecosystems controlled by humans, adopting the correct approach to a wide range of production issues requires an understanding of the way in which natural and human-driven or forced processes interact within the ecosystem.

Agronomists have argued that the missionsof multi-objective agriculture could best be achieved by making better use of biological regulation mechanisms at different levels: crop management, cropping system design, landscape layout and management (Matson et al., 1997; Médiène et al., 2011). This assumes that biological mechanisms are able to replace chemical or physical inputs, or to interact favourably with them, playing the same agronomic role without external costs, including environmental costs in particular.The use of biological regulation in agroecosystems to achieve both a high level of food production and to provide ecosystem services, apparently opposite aims, has been placed at the core of what is 
increasingly called "ecological intensification". The Food and Agriculture Organisation (FAO, 2009)recently defined "ecological intensification" (or "sustainable intensification") within the framework of organic agriculture as "Maximization of primary production per unit area without compromising the ability of the system to sustain its productive capacity". The expression"ecological intensification" was already in usemore than two decades ago (Egger, 1986), when it referred to a kind of ecological engineering in agropastoral systems in Africa, replacing some perennial species to improve soil organic matter content.

A more recent use of the expression by Cassman (1999)focused on cereal production and highlighted the need for progress in plant and soil science to achieve a continuous increase in cereal yields (intensification) without environmental (ecological) damage.This approach focuses principally on the fate of fertilisers and their use by crops. Witt et al. (2006) applied a similar approach to oil palm plantations. According toChevassus-au-Louis and Griffon (2008)and a number of other authors (Affholder et al., 2008; Mikolasec et al., 2009; Hubert et al., 2010; Bommel et al., 2010),ecological intensification is a pathway towards the production ofmore agricultural product, the production of "new" things (ecosystem services) and different means of production (environmentally friendly). According to Chevassus-auLouis and Griffon (2008), ecological intensification is basedon "intensification in the use of the natural functionalities that ecosystems offer". Though relatively vague, this definition remains a possible starting point for the consideration of alternative pathways of development foragriculture. This definition is much broader than that of Cassman (Cassman, 1999), and provides an interestinghaven for scientists promoting the use of biological regulation in agroecosystems. 
109 Many articles have been published on biological regulation in agroecosystems, mostly under

110 the heading "agroecology", and new papers are continuing to appear. Research on this topic

111 remains highly necessary, and is probably a challenge for most agronomists familiar with

112 individualphysical and/or chemical aspects of agroecosystems. However, ecological

113 intensification calls for both a wider diversification of sources of knowledge and the

114 development of new data analysis methods. Agronomists have, until recently, relied

115 essentially on their own scientific output. Prototyping (e.g. Vereijken, 1997; Lançon et al.,

116 2007; Debaeke et al., 2009) and the model-based design of agricultural systems (e.g. Rossing

117 et al., 1997; Bergez et al., 2010) are fed by results processed through simulation studies,

118 statistical hypothesis testing and group analysis, from research groups working mostly at

119 experimental stations(Figure 1). We argue here that agronomists would be placed in a better

120 position to tackle ecological intensification if they diversified their sources of knowledge and

121 the methods used to compile, organise and analyse such knowledge. The diversification of

122 knowledge sources may include (i) making use of recent advances in plant sciences, (ii)

123 learning lessons from the functioning of natural ecosystems, guiding the design and

124 management of acroecosystems and (iii) embracing local farmers' knowledge. Methods for

125 assessing these sources of knowledge are necessarily diverse, and couldbe extendedto data

126 mining and the meta-analysis of large datasets containing heterogeneous information and

127 comparative analyses of agroecosystems at different scales. We present here the arguments

128 for further agronomic research in these two related domains: sources of knowledgefor

129 agronomists and data processing methods.

130

131 2. Diversifyingsources of knowledge to guide ecological intensification

$132 \quad 2.1$ - Mobilizingadvances in plant sciences 
133 There has been tremendous progress in plant sciences in recent decades, with detailed

134 elucidation of the genetic and environmental determinism of plant development, growth and

135 reproduction. This progress was made possible, in particular, by increases in our ability

136 todissect cellular and molecular processes, supported by exponential progress in laboratory

137 techniques and the capacity to analyse masses of genomic data (e.g. Tardieu \& Tuberosa, 138 2010). This knowledge about the highly complex life of plants has often been developed in a

139 simplified environment, far removed from the reality of farmers' fields. This has led to a

140 widening of the gap between the research objectives of plant scientists and agronomists. We

141 highlight briefly, with a few examples,ways in which agronomists could make use of

142 advances in plant sciencesto designecologically intensive cropping systems.

\section{$144 \quad$ 2.1.1.A new look at the basics}

145 Agronomists involved in the design and evaluation of cropping systems often make use of a

146 simplified crop description(Monteith 1977),despite the availability of more mechanistic

147 models simulating canopy photosynthesis (Spitters et al., 1986; Spitters 1986; Depury \&

148 Farquhar, 1997).In this simplified description, the canopy, represented as a "big leaf",

149 intercepts photosynthetically active radiation and converts it to biomass. Branching is

150 generally considered to be the outcome of interplant competition. Mineral nutrition is

151 represented as a simple flux from soil to plant roots, depending on soil mineral and water

152 contents. Such simplified representations have proved sufficient and highly successful for

153 cropping system design. Moreover, the more sophisticated representations of the basic

154 processes of plant life implemented in more complex models do not necessarily improvethe

155 ability of crop models to predict behaviour in a range of fluctuating conditions. Such

156 representations have therefore been used only rarely by agronomists. Nevertheless, results

157 recently obtained in plant sciences suggest that this simple paradigm could be improved, as 
158 shown for example by Zhu et al. (2010), who analysedthe ways in which improvements in

159 photosynthesis efficiency could contribute to the required increase in yields.

161 Nutrient use efficiency is alsoclearlya keypoint in ecological intensification. One of the most

162 important issues is decreasing the use of nitrogen fertilisers, to decrease greenhouse gas

163 emissions, to reduce the dependence of agriculture on fossil fuels and to prevent health and

164 environmental disorders, without decreasing productivity (Galloway et al., 2008; Spiertz, 165 2010). Plant scientists have investigated in detail the exchanges of nitrogen between roots and 166 their environment (Jackson et al., 2008). Glass (2003) summarised the factors decreasing 167 nitrogen absorption efficiency, on the basis of molecular knowledge and empirical data. 168 Decreases in nitrogen transporter activity and rates of nitrate absorption follow increases in 169 soil ammonium concentration, low temperature and incident radiation. These mechanisms 170 may account, at least in part, for the high variability of fertiliser efficiency observed in field 171 experiments. They also provide us with opportunities to improve nitrogen management in the 172 soil. More generally, the ways in which plants make use of adaptation mechanisms to deal 173 with mineral depletion have been extensively studied on a physiological basis (Grossman \& 174 Takahashi, 2001). Agronomists could make use of this work to define the limitswithin which 175 plant environments must be contained to avoid unfavourable plant reactions.

\section{$177 \quad$ 2.1.2. The cultivated plant and its biological environment}

178 Since the middle of the last century, the gradual "artificialisation" of agriculture has led to

179 agronomists paying less attention to the biological components of fields. Agroecology has 180 emerged as a reaction against this excessive simplification of the system, placing the 181 biological component back at the heart of the system (Altieri, 1989), and resulting in the 182 development of an“agroecosystem"view (Conway, 1987). Nevertheless, common agronomic 
183 practices still largely ignore biological interactions in cultivated fields, and agroecologists

184 often emphasise the need for an empirical and holistic approach to agroecosystems. New

185 findings in plant sciences concerning the relationships between the plant and its surrounding

186 biotic environment have recently emerged and are of great interest.

188 Studies of interactions between roots and soil micro-and macro-organisms have revealed the

189 existence of processes of paramount importance for agronomists. Some of these interactions 190 are very familiar to agronomists, including nitrogen fixation by symbiosis between Rhizobium 191 sp.and leguminous or non-leguminous(Mehboob et al., 2009) plants. Other associations, such 192 as that between other endophytic di-azotrophic bacteria and grasses or cereals, also exist and 193 may be of interest, as pointed out by Reis et al. (2000). Plants may be injured by soil

194 pathogenic organisms, but they may also benefit from organisms present in the rhizosphere, 195 through improvements in growth and mineral nutrition, an increase in resistance to 196 unfavourable abiotic conditions, and protection against or an increase in resistance to 197 pathogens (Sturz \& Nowak, 2000; Kiers and Denison, 2008).

199 Whatever the types of organisms considered, the species or plant genotype drives selection of 200 the bacterial community and determines the benefits of plant-rhizosphere mutualism. 201 Improvements in the genomic characterisation of rhizobacterial communities have made it 202 possible to demonstrate that plant genotype influences bacterial assemblages by modifying 203 exudation patterns (Micallef et al., 2009). An understanding of the plant genome would make 204 it possible to determine the genetic basis of the mechanism and to make use of genetic 205 variants for the management and manipulation of the rhizosphere community (Ryan et al., 206 2009; Wissuwa et al., 2009). These rhizosphere associations and their benefits to the crop also 207 depend strongly on cropping system, so it would seem reasonable to conclude that adapted 
cropping systems (including crop rotation and crop management measures) could also 209 increase efficiency. The efficacy of the Rhizobium/legume association is also highly 210 dependent on cropping system, through the effects of practices on the physical and chemical 211 properties of soils and their water status (Sprent et al., 1987). These effects are well known, 212 but should be considered in the light of the recent development of legume nodulation 213 genomics (Stacey et al., 2006). Sturz and Nowak (2000) have enlarged their vision to the 214 overall communities of endophytic rhizobacteria with potentially beneficial effects on crop 215 growth through an increase in resistance to unfavourable abiotic conditions and to pathogen 216 aggression, and through improvements in growth and mineral nutrition. The agronomic 217 benefits of these associations with endophytic rhizobacteria depend on the survival of 218 bacterial communities, which in turn depends on soil and crop management (Bowen and 219 Rovira, 1999; Acosta-Martinez et al., 2008). One of the ways by which crop management can modulate the evolution of microbial communities, is its effect on root exudates. In addition to 221 altering the physical and chemical properties of the soil, root exudates have been shown to 222 affect both soil micro-organism communities and other eukaryotes (Bertin et al., 2003). Bais 223 et al. $(2004,2006)$ reviewed the nature of the chemicals involved and the corresponding 224 interaction processes for various ecological roles. However, one of the aspects of crop/soil community interactions most frequently ignored by agronomists is probably the role of the common mycorrhizal networks (CMNs), which may be affected directly or indirectly by soil

227 tillage, fertilisers, pesticide use and aerial plant management (Pietikainen \& Kytoviita, 2007). 228 The networks that these fungi establish between plants may provide a major route for mineral 229 transfer from plant to plant (He et al. 2003). Van der Heijden and Horton (2009) recently 230 reviewed the possibilities for CMN formation between different plant species, their ecological 231 significance and the benefits generated. They found that there were many possibilities for 232 CMN development, but that there were also large differences in the benefits accrued, 
233 particularly in terms of promotion of the growth of interconnected plants. Similarly, the role 234 of plant micro-organisms in plant x plant interactions (Sanon et al., 2009; Li et al., 2008) and 235 the competition of microbial communities promoting both plant growth and health 236 (Lemanceau et al., 2009) illustrate the benefits that agronomists may obtain from advances in 237 research on plant-micro-organism interactions for rhizosphere engineering and management 238 (Ryan et al., 2009). Beyond the question of production, Jackson et al. (2008), focusing on 239 nitrogen, derived from current knowledge on root/micro-organism interactions the trends in 240 ecosystem services supplied by cropping systems in different agricultural situations. Thanks 241 to the deep insight now available, the contribution of agronomists at system level can be built 242 on mechanistic rather than empirical knowledge, as demonstrated by certain examples in 243 precision agriculture(Welbaum et al., 2004).

Interactions between aerial parts of the plant and the surrounding biotic environment have also been described in detail in recent years. The metabolic pathways bywhich plants react both locally and systemically to infection or wounding are increasingly well known (De

248 Bruxelles \& Roberts, 2001; Kessler \& Baldwin, 2002). Some result in the production of 249 volatile substances, which play a role in herbivore repulsion or plant-to-plant signalling. 250 These findings are promising for genetic engineering approaches, provided that the genetic 251 basis of the metabolic pathways can be identified (Dudareva \& Pichersky, 2008). 252 However,cropping system may also play a role, as the expression of the metabolic pathways 253 involved in direct or indirect defence probably depends on interactions between genotype and 254 environment (Le Bot et al., 2009). Moreover, it may be possible to elicit some of these 255 pathways deliberately, with appropriate techniques. 
The preceding two sections do not provide a detailed review of the extensive literature in

259 plant sciences. Instead, they deal with a few examples of recent progress and the possible 260 benefits that agronomists could derive from these advances (see table 1). These examples 261 demonstrate that closer consideration of the results of plant sciences could help agronomists 262 to reach their objectives, paving the way for higher levels of production, better quality 263 products, and less harmful consequences for the environment.Other advances in plant 264 sciences, concerningplant architecture, leaf and root morphogenesis (McSteen \& Leyser, 265 2005; Wang \& Li, 2008; Walter et al., 2009),floral biology (e.g. Boss et al., 2004), the role of aquaporins (e.g. Maurel et al., 2008), cell separation processes (Roberts et al., 2002) and long 267 distance signals within plants (Lough \& Lucas, 2006), for example, are also of great potential 268 interest to agronomists working on ecological intensification,as they might help crops to avoid 269 or to resist deleterious stresses. However,major efforts are still required to scale-up the results 270 from individual genes, cells or organs to the canopy, and to test the stability of biological 271 results in a wide range of agricultural conditions. It is also important to check that advances in 272 one area are not associated with severe drawbacks in others. However, these findings are 273 nonetheless precious to agronomists, who will need to use all the means available to construct 274 novel, more resource-use efficient and/or productivecropping systems.

276 Finally, there are many different drivers of change in ecological intensification (see 277 introduction and subsequent sections). Innovative systems that have already been developed 278 in the domain of ecological intensification, such as the use of mixtures of cultivars or species, 279 agroforestry andno-tillage systems, would certainly benefit from the knowledge provided by 280 plant sciences. However, these systems will themselves raise new questions and issue new 281 challenges to plant science. For example, although progress has been made in this area, plant 282 sciences results are still often obtained in highlysimplified systems and therefore cannot easily 
be translated to multispecies systems. Above-ground competition for light and below-ground

284 competition for water are major processes inecological intensification that require study in 285 systems including facilitation between plants (Long \& Nair, 1999;Zhang et al., 2008; 286 Malézieux et al., 2009).

\section{2 - Learninglessons from the functioning of natural ecosystems}

289 Strategies for agroecosystem design and management may be derived from the observation of natural ecosystems, guiding alternative agronomic practices (Malézieux, 2011). Several authors (e.g. Ewel, 1999; Altieri, 2002; Jackson, 2002; Vandermeer, 2003) have already suggested that natural ecosystems may provide appropriate models for agroecosystem design to achieve both environmental and social goals while ensuring long-term sustainability. This

294 idea is basedon the assumption that natural ecosystems are adapted to local constraints, due to 295 a long process of natural selection (Dawson \& Fry, 1998; Ewel, 1999). It is therefore assumed 296 that the incorporation of certain characteristics of natural ecosystems into agroecosystems 297 would improve some of the properties of agroecosystems, such as productivity (Fukai, 1993), 298 stability (Aerts, 1999; Schulte et al., 2002) and resilience (Lefroy et al., 1999). These features 299 are particularly useful for dealing with pest outbreaks (Trenbath, 1993) and increasing energy 300 efficiency in a context of the depletion of fossil fuels (Hatfield, 1997). A similar reasoning 301 was followed in the framework of Ecoagriculture, proposed by McNeely andScherr (2003), 302 which places biodiversity at the heart of strategies to conserve and restore ecosystem services, 303 increase wild populations in agroecosystems, and sustain agricultural production. An 304 illustration of this mimicry is providedfor cropping systems in Figure 2 with an emphasis on 305 crop protection. In natural ecosystems, the various animal and plant species interact through 306 population dynamics and trophic networks, providing the final ecosystem with services, such 307 as pollination. In standard cropping systems, these interactions may lead to pest damage on 
crops, which may be managed with various control methods to limit yield loss. An increase in

309 plant species diversity in systems mimicking natural ecosystems could allow natural enemies to control pests and generate ecosystem services.

\subsubsection{What does "Mimicking natural ecosystems" mean?}

314 There have been only a few practical attempts to design agroecosystems from nature. Jackson and Jackson (1999) aimed to develop sustainable cropping systems by mimicking the midgrass American prairie, creating crop mixtures analogous to the vegetationstructure of the

317 prairie. Traditional agroecosystems in the tropics, long unknown or disparaged by some 318 agronomists, are frequently based on the integrated management of local natural resources 319 and, in many cases, on the management of local biodiversity. These systems may also be considered to result from the observation of nearby natural ecosystems by generations of

321 farmers, who have aimed to mimic the functioning and structure of these natural systems. For 322 example, slash and burn systems can be considered to mimic nature behaviour after fire. 323 Agroforestry systems in the humid tropics mimic the structure and functioning of rainforests. 324 According to Ewel (1999), humid tropical ecosystems appear to be particularly suitable for application of the "mimicry of Nature" concept. Agroforestry systems in the humid tropics are 326 based on the tropical rainforest model. They combine several strata, have a high level of 327 species diversity and are very widespread in Asia, Oceania, Africa and Latin America. Such 328 systemsprovideboth subsistence for local populations and major environmental and socio329 economic services (Sanchez, 1995; Nair, 2001). Lying halfway between agro- and forest ecosystems, agroforestry systems combine annual and perennial, herbaceous and woody 331 species, in a more or less complex whole in terms of the number of plant species and practices 332 (Torquebiau, 2007). The damar agroforests of Sumatra, or the cocoa-based agroforests of 
333 Cameroon or Costa Rica, are original ways in which farming communities use natural

334 resources in human reconstructions of both "natural" and productive ecosystems from natural ecosystems (Michon et al., 1995, 2007; Schroth et al., 2001, 2004).

The scientific foundations of the mimicry paradigm, however, remain to be studied

338 thoroughly (Malézieux, 2011). The potential of this approach to generate innovative

339 agroecosystems in practice also remains largely unknown. Ewel (1999) and Van Noordwijck 340 and Ong (1999) proposed two principles for the design of agroecosystems based onnatural 341 ecosystem mimicry. According to the first of these principles, agroecosystems should mimic 342 the structure and function of natural ecosystems existing in a given pedoclimatic zone. 343 According to the second, agroecosystems should also mimic the diversity of species existing 344 in natural ecosystems, thereby maintaining the diversity of natural ecosystems in the given 345 zone. The first of these principles is clear enough, but must be extended to be effective. 346 Indeed, there are many functions, and structure can be assessed at different scales. 347 Furthermore, basing agroecosytem design solely on natural ecosystems present in the same 348 area may be too limiting: some good ideas might emerge from the study of very distant 349 systems.

351 According to the second principle, the redesign of agroecosystems inmore ecologically 352 intensive configurations implies their diversification. This has been the case, for example, in 353 Cuba, where small- and medium-scale farmers have tended to diversify their production 354 systems in response to their limited access to or total lack of agricultural inputs to sustain 355 productivity (Funez-Monzote et al., 2009).The resulting diversified systems areenergetically 356 more efficient, less dependent on external inputs, more productive, adaptable and resilient. 357 The diversification of agroecosystems within the mimicry paradigm may be achieved by 
358 increasing the number of microorganisms, plant and animal species relevant to agriculture overspace and time, or through agrobiodiversity, a subset of general biodiversity (Brookfield et al., 2003). However, natural ecosystem mimicry cannot mean reproducing the diversity 361 observed in natural ecosystems, for at least three reasons. First, recent reviews of existing 362 knowledge in ecology have demonstrated that functional composition controls ecosystem 363 functioning more frequently than species diversity (Hooper et al., 2005). As our purpose is to 364 improve agroecosystem functioning through ecological intensification, and not to conserve 365 natural species biodiversity per se within agroecosystems, agronomists should concentrate on identification of the level of functional biodiversity resulting in the expression of interesting 367 properties. As pointed outby Main (1999), who addressed the question of how much 368 biodiversity is enough in the context of agroecosystems mimicking nature, the level of 369 diversity considered adequate strongly depends on the goals and criteria used forevaluation. 370 Moreover, interesting properties may arise from the spatial and temporal organisation of the 371 species rather than purely from their number. For example, lessons can be learnedfrom studies 372 of natural ecosystems addressing agronomic topics: nutrient cycling within a complex 373 landscapemay be useful for optimising nutrient management in areas worked by humans, 374 community ecology in natural ecosystems may facilitate the design of new crop protection strategies and an understanding of facilitation within natural ecosystems should make it easier

376 to make use ofthis process in agroecosystems. Finally, approaches based on mimicking 377 natural ecosystems will inevitably be confronted with the "aim problem". Natural ecosystems 378 provide many services but are not targeted. Agroecosystems, by contrast, are designed to 379 optimise different aspects and toachieve different goals. Consequently approaches mimicking 380 natural ecosystems are limited by certainagricultural obligations, such as the removal of the 381 minerals contained in agricultural products. Some insight may be gained from regarding 
agroecosystems as complex systems with many simultaneous feedback loops including a

383 dimension absent from natural ecosystems: human agency.

\subsubsection{Agroecosystems as complex socio-ecological systems}

Agroecosystems are systems that combine sociological and ecological dynamics, in interaction.In complex, dynamic and spatially heterogeneous systems, interactions take place over scales generating emergent properties and self-regulatory mechanisms (Holling, 1973). These mechanisms often manifest as cross-scale feedback, or panarchy (Gunderson et al., 2002), and societies contribute to system regulation through adaptive management. For example, in smallholder agricultural systems making use of communally shared resources,

392 buffering and regulatory mechanisms often emerge from collective action (Meinzen-Dick et 393 al., 2004). This is why agroecosystems may be defined as socio-ecological systems, or 394 cybernetic systems steered by humans to attain certain goals (see Conway, 1987). The 395 capacity of farmers to adapt plays a major role in system resilience and, byanalogy to the 396 concept of informal economies (de Soto, 2000), regulatory mechanisms operate as informal 397 resource flows that are often unaccounted for in agroecosystems analysis (Tittonell et al., 398 2009). Just as natural ecosystems have a"memory"as a direct consequence of their history, so 399 do agroecosystems, except that some of that memory lies in human agency (Tittonell, 2007).

401 A wider definition of agroecosystem diversification, more compatible with the socio402 ecological nature of complex agroecosystems, must consider not only species diversity, but 403 also the diversity of agricultural practices and rural knowledge adapted to/derived from local 404 pedoclimatic conditions. These lie at the core of human agency and represent new sources of 405 knowledge for agronomic research (see below). Agroecosystem diversification in its 406 broadestsense thus concerns the diversity of livelihood strategies ata certain location, diverse 
land use, management and marketing strategies, the integration of production activities (e.g.

408 crop-livestock interactions), spatial and temporal associations of crops and crop cultivars, and

409 the maintenance of genetic agrobiodiversity in the system. The efficiency of use of natural,

410 economic and social resources in agroecosystems — which goes beyond the partial use

411 efficiency of a certain single input —and desirable properties, such as stability and

412 resilience,are based on one or more of these categories of diversity. New avenues for

413 agronomy to strengthen agroecological intensification should go beyond the cultivated field or

414 the mixture of species in a given landscape. They should explore desirable properties and

415 mechanisms that operate at the scale of complex socio-ecological systems i.e.that take into

416 account sociological and ecological dynamics and interactions in agroecosystems.

\section{3 - Farmers' knowledge and lay expertisevalorisation and integration into scientific}

\section{9 knowledge}

420 Farmers do not rely exclusively on the results and output of agronomic research to operate 421 their agroecosystems. They make use ofmuch wider knowledge, based on their own 422 experiences and on exchanges with other farmers and advisers, thus building their own 423 expertise. This expertise is rooted in the need to act whatever the level ofagronomic 424 knowledge available: sound and detailed or unreliable and patchy. It is also dependent on the 425 characteristics (environmental, economic, social) of the situation in which it is constructed. 426 According toPrior (2003), we may consider farmers to belay experts (although this 427 denomination entails an antinomy): experts because of their experience-basedknowledge 428 andlay because this knowledge is limited in scope and doesnot give farmersthe broader and 429 deductive understanding characteristic of scientific or expert knowledge. Recognition of the 430 value of lay expertise is both a necessity and a challenge in many domains, such as medicine 431 (e.g. adapting treatments according to the patient's reactions, both as observed by doctors and 
as interpreted by the patient) and industry (particularlyfor fault detection in plant or machine

433 operation). However, although the value of this lay expertise is recognized, it is not used to

434 build or extend the current scientific knowledge, but to adapt its application in local situations

435 (Henderson, 2010).

437 Farmers can observe not only their own production systems, but also other systems (both 438 agricultural and natural) and interactions between these systems. They can also 439 gainexperimental knowledge in their own systems. They are often willing to do so and 440 therefore carry out experiments in the operation of their own agroecosystem, evaluating the 441 response of the system to their decisions. This generates different types of knowledge. When 442 confronted with, observing or learning from natural ecosystems, farmers gain knowledge 443 similar to what is generally referred to as local or traditional ecological knowledge (LEK or 444 TEK, Berkes, 1999). Over generations, they may also build traditional knowledge (not 445 specifically ecological), refined by years of adaptation (see previous section). When 446 experimenting, they build a mixture of experience-basedand experimental knowledge. Many 447 studies have considered the use of LEK/TEK, but most have focused on the use of this 448 knowledge for natural resource management (including fisheries and forestry systems, which 449 more closely resemble a subsistence harvesting activity) rather than the design or 450 improvement of productive agricultural systems. Fewer studies have directly investigated 451 farmers' knowledge. The studies that have been carried out in this domain have mostly 452 assessed the validity of this knowledge (e.g.Grossman, 2003; Friedman et al., 2007; Grace et $453 a l, 2009$ ) or considered the local adaptation of more generic solutions (e.g. Steiner, 1998, 454 Affholder et al., 2010). However, farmers' knowledge is not only of value for application and 455 for the adaptation of agronomic knowledge to a particular case. It can also be used to extend 
the available scientific agronomic knowledge (see the examples presented in Table 2). We

457 will defend this point and discuss the various issues it raises below.

\subsubsection{Value of farmers' knowledge for agronomy}

460 We will analyse separately the lay expertise (resulting from farmers' activities and 461 interactions with their own systems) and the more traditional knowledge that some farmers or 462 societies have developedover time. The value of lay expertise for agronomy and for 463 development (support to farmers) has been recognised for some time (e.g. Barzman et al., 464 1996; Baars \& de Vries, 1999). This lay expertise can helpto enlargecurrent agronomic 465 knowledge in variousways. First, farmers operate their agroecosystem even in the absence of 466 appropriate knowledge, because they have to. They therefore develop experience-based 467 knowledge that can fill in some of the gaps in scientific knowledge. However, as mentioned above, this experience-based knowledge is often limited to the farmer's own particular case, whereas scientific knowledge should be more general.

471 Second, some traditional practices are based on the observation of natural ecosystems 472 (Chalmers \& Fabricius, 2007; Reed et al., 2007), which, as we have seen, may be of value 473 forecological intensification. Chalmers \& Fabricius (2007), for example, showed that local 474 experts, using their ecological knowledge, were able to put forward explanations for changes 475 intheir system, some of which were also provided by scientific knowledge. However,the local 476 experts also had other explanations rooted in a more generalunderstanding of the system. 477 Traditional farming systems can also be a source of understanding and inspiration for the 478 design of sustainable farming systems. Singh \& Sureja (2008) showed, for example, how 479 traditional farming systems cope with harsh environments through the management of a wide 480 diversity of plants providing genetic resources. Abbona et al. (2007) evaluated the 
sustainability of a traditional vineyard system in Argentina, both in its original location and in a newly planted area. They showed that the traditional system, in its original location, wasindeed sustainable, whereas this system was not sustainable in its new, different location. They concluded that the efficacy of the traditional system was dependent on the location in which and for which it had been developed over time. During this evaluation process, based on the use of indicators developed for this analysis through the adaptation of existing methods, these authors gained insight into and an understanding of the ecological processes at work in the traditional vineyard system. The analysis of traditional farmers' practices therefore provided an opportunity to obtain new scientific knowledge. In a different context, Ballard et al. (2008) analysed the knowledge involved in the management and monitoring activities of community-based forestry groups and the ways in which local and scientific knowledge complemented each other. They showed that local knowledge provided a rapid and efficient means of assessing the effects of management practices on the forest. The same was found forgreenhouse tomatomanagement. Tchamitchian et al. (2006) successfully used the concept of "crop vigour" as an indicator in their expert system controlling the daily greenhouse climate for tomato production. Tomato cropvigour is readily assessed by growers of greenhouse tomato crops, on the basis of a set of observations: plant tip colour and shape, fruit load on the crop, crop overall colour. Scientists relate these observations to the generative to vegetative balance of the crop and its ability to perform photosynthesis(Navarrete et al. 1997), without being able to model it formally.

Taken as a whole, local knowledge and lay expertise can provide clues to the natural or ecological processes most useful in the design of sustainable farming systems, such as the natural regulation of pest populations by their predators (Barzman et al., 1996; Sinzogan et al. 2004), or management of the soil and its mineral balance (Steiner, 1998; Okoba \& de Graaf, 
2005; Saito et al., 2006; Abbona et al., 2007). They can also be of value in the design of

507 assessment methods or indicators for monitoring the ecological performances of these farming systems.

\subsubsection{Qualification and validation of lay expertise and knowledge expression}

511 Although both interesting and challenging, the lay expertise of farmers (or advisers) is not

512 easy to use. First, this lay expertise must be elicited and represented. Several methodologies have been proposed for expert knowledge elicitation, either for specific applications, such as

514 plant disease epidemics (Hughes \& Madden, 2002), or for more general applications

515 (Cornelissen et al., 2003; Ley et al., 2010). Appropriate elicitation methods include the 516 selection of apanel of experts and the associated delimitation of the knowledge domain 517 considered. The choice of representation also influences the elicitation process. Many authors 518 advocate the use of fuzzy models, which allow the use of linguistic terms and are more 519 suitable for the expression of knowledge in qualitative rather than quantitative terms. By 520 contrast, scientific knowledge is most frequently modelled in quantitative terms, 521 particularlywhen the goal is to represent the operation of a system under the influence of both 522 controlled (human decisions and actions) and uncontrolled (environment) factors. Most of the 523 agronomic models built to simulate agroecosystems are numerical models in which 524 thevariables have point values rather than interval or probabilistic values. There is therefore a 525 gap between the most common representation of scientific knowledge and that of lay 526 expertise, hindering the combination and merging of these two types of knowledge. However, 527 differences in representation are not the only difficulty. As pointed outby Prior (2003), lay 528 experts maybe wrong, either because of the limited scope of their experience or because their 529 conclusions are based on false premises (misobservations, for example, due to a lack of 530 knowledge or skills). Their knowledge is also situation-dependent in that it is obtained in a 
531 domain of low variability (one of the goals of agricultural practices is often to reduce

532 variability and diversity in agroecosystems,a goal challenged byecological intensification).

533 Lay expertise should therefore be qualified and analysed independently, in several different

534 ways: domain of validity, certainty and precision. The domain of validity is important because

535 knowledge should be associated witha description of the domain in which it was obtained

536 (rangesof the variables considered, for example); this factor can be used to analyse the extent

537 to which the knowledge obtained is generic. Certainty refers to the confidence that can be

538 attributedto the knowledge. Finally, precision measures how close to a numerical expression it

539 is possible to get in the expression of the knowledge. Even certain knowledge may display a

540 low precision rendering its use purely hypothetical (ventilating a greenhouse does modify its

541 temperature, but the change is difficult to indicate with precision). Artificial intelligence

542 provides a framework for representing expertise and analysing the conflicts arising when

543 information from different sources is compared (several lay experts or a combination of lay

544 expertise and scientific knowledge; Amgoud \& Kaci, 2007; Bench-Capon \& Dunne, 2007;

545 Alsinet et al. 2008; Amgoud \& Prade, 2009). However, this domain (qualitative reasoning and

546 argumentation) is still developing and, to our knowledge, its concepts and tools have not yet

547 been used to merge lay expertise and scientific knowledge in agronomy (there are applications

548 for database fusion, assisting debate preparation and industrial planning). The added value of

549 these approaches lies in the need to providean explanation detailing the arguments supporting

550 a piece of knowledge, therefore addressing the questions of certainty and precisionraised

551 above.

552

553 The qualification of lay expertise has been shown to be a necessary step in approaches aiming

554 to combine this expertisewith scientific knowledge. Going beyond the issues of the domain of 555 validity, certainty and precision, there is the question of validation of the new knowledge 
obtained. However, classical validation procedures cannot readily be applied, because the

557 observations underlying the experience-based knowledge acquired are lacking. For example,

558 to validate the greenhouse management rules formalised from expert knowledge,

559 Tchamitchian et al. (2006) used a two-step method rather than a direct validation of the rules

560 themselves, which was not possible. The first step involved checking that the application of

561 these rules really did result in the desired pattern of behaviour in the greenhouse (as expressed

562 when building the rules), without questioning the agronomic validity of this behaviour. The

563 second step involvedassessingthe quality of production obtained by applying these rules, the

564 goal being to obtain appropriate production levels from the greenhouse. Attempts at the direct

565 validation of a given rule have only made explicit which pieces of agronomic knowledge can

566 be used to support a given rule. However, it would not have been possible to designthe rule

567 from this identified scientific knowledge, generally because the scopes of the scientific 568 knowledge and that of the lay expertise yielding the rule were different.

\section{Methods for synthesizing information}

571 The three main research methods currently used by agronomists (figure 1)are varioustypes of 572 field experiments, on-farm inquiries (e.g. Doré et al., 2008), and modelling (e.g. Rossing et 573 al., 1997; Bergez et al., 2010). Field experiments provide validated knowledge meeting the 574 scientific rules for data acquisition. This basic knowledge can be supplemented by inquiries 575 providing data from real-world agricultural situations (farms). Modelling can be used to 576 explore the response of key agronomic and environmental variables, such as,for 577 example,yield or nitrogen loss, to climate, cropping system variables or societal changes. 578 Thedata generated are then processed, mostly byclassical methods,such as simulation studies, single-experiment data analysis, or group analysis.These methods could probably be 
results from a series of studies, and comparative analyses of agroecosystems, involving the use of large-scale comparisons similar to those used in ecology (e.g. Fortunel et al., 2009).

\subsection{Meta-analysis and agronomy}

Meta-analysis (e.g., Borenstein et al., 2009)is more powerful than a simple narrative review of a series of studies, because it synthesises published data in a quantitative manner and makes it possible to assess thebetween-study variability of a variable of interest.

Both scientific researchers and decision-makers can benefit from meta-analysis in several ways (Sutton et al., 2000), as this approachprovides a methodological framework for (i) exploringwhat has already been done on a given research topic and identifying more clearly where the gaps and uncertaintieslie,(ii)generating an overview ofdivergent results, (iii) guidingdecisions based on a systematic review and statistical analysis of all the available data related to a given topic, (iv) broadening the knowledge base and allowing replication for the testing of hypotheses, (v) adding to the cumulative development of science.

Most meta-analyses carried out to date have been performed in medical science (Normand, 1999; Sutton et al., 2000). This approach has been less systematically applied in other areas of research, such as ecology (e.g., Arnqvist \& Wooster, 1995; Cardinaleet al., 2006), and has sometimes been applied inagriculture (e.g. Bengtsson et al., 2005), animal science (Sauvant et al. 2008) and plant pathology (Rosenberg et al., 2004). In agronomy, meta-analysis methods have generally been used to compare the effects of different cropping techniques or of different cropping systems on yield or biomass production. For example, Miguez \& Bollero (2005) used a meta-analysis method to summarise and describequantitatively the effect of several winter cover crops on maize yield. The authors estimated the ratio of maize yield after 
606 a winter cover crop to maize yield with no cover from 37 published studies carried out in

607 various regions of the USA and Canada. In another study, Miguez et al. (2008) studied the 608 effects of planting density and nitrogen fertiliser on the biomass production of Miscanthus $x$ 609 giganteus, using 31 published studies including biomass measurements at different dates 610 overseveral years. Drawing on published studies on sub-Saharan African agriculture, 611 Chikowo et al. (2010) conducted a meta-analysis of factors controlling nitrogen and 612 phosphorus capture and conversion efficiencies by major cereal crops. The meta-analysis 613 carried out by Badgley et al. (2007) did not focus on a specific cropping technique, but was 614 performed to compare two agricultural systems: organic versus conventional or low-intensity. 615 The authors compared the yields obtained in an organic system with those obtained in 616 conventional or low-intensity food production systems, based on yield data from293 617 individual studies on various crops. These data were used to estimate the meanyield ratio for 618 variousfood categories, for both developed and developing countries.

620 Diverse techniques for meta-analysis are available (e.g., Borenstein et al. 2009; Sutton et al., 621 2000), but meta-analysis should always include the following steps:

622 i. Definition of the objective of the meta-analysis and of the variable of interest to be estimated from the data (e.g., in Miguez and Bollero 2005, the variable of interest is the ratio of maize yield after a winter cover crop to maize yield in the absence of a cover crop).

ii. Systematic review of the literature and/or of the dataset reporting values of the quantities of interest. measurement techniques). 
iv. Assessment of between-study variability and heterogeneity. Evaluation of the between-study variability of the variable of interest and of the heterogeneity of the accuracy of individual estimates is an important step in a meta-analysis and several statistical methods have been proposed to estimate between- and within-study variances (Borenstein et al., 2009). Combination of the individual study estimates and estimation of a mean value for the variable of interest, for example, can be achieved by calculating a weighted sum of individual estimates derived from the studies collected in step ii. highly significant results are published. In this case, a meta-analysis can lead to a biased conclusion and overestimation of the effect of a given factor. The 'funnel plot' technique can be used to deal with this issue (e.g., Borenstein et al., 2009).

645 In the context of ecological intensification, the meta-analysis framework constitutes an 646 interesting alternative to dynamic crop models. Dynamic crop models can be used both to 647 assess the consequences of cropping techniques and environmental variables forcrop 648 production (e.g., Jones \& Thornton, 2003) and to assess the effect of cropping systems on 649 keyenvironmental variables (e.g., Rolland et al., 2008), two key issues for ecological 650 intensification. However,these models include several sources of uncertainty (Monod et al., 651 2006) and their predictions are not always reliable (e.g., Barbottin et al., 2008; Makowski et $652 a l ., 2009)$. We believe that meta-analysis should be more systematically used by agronomists, 653 to assess and compare the effects of cropping systems on productivity, risks of soil and water 654 pollution, greenhouse gas emissions and biodiversity. A considerable body of experimental 
655 data is available for such purposes (e.g., Rochette \& Janzen, 2005). Such data could be

656 reviewed, combinedand analysed withstatistical techniques, to rank cropping systems as a

657 function of their impact on key environmental variables, such as water nitrate content,

658 greenhouse gas emissions (e.g., $\mathrm{N}_{2} \mathrm{O}$ ) and the presence/absence of species of ecological

659 interest (e.g., earthworms, birds). However, meta-analysis requires the use of appropriate

660 techniques and the value of a meta-analysis may be greatly decreased if the six steps outlined

661 above are not rigorously implemented.

662

663

\subsection{Comparative analysis of agroecosystems}

664 Informationuseful for the ecological intensification of agroecosystems may be obtainedfrom 665 comparative analyses of the structural and functional properties and performance of 666 contrasting agroecosystems. Similar approaches, based on temporal or spatial comparisons, 667 are used in other fields of research, such as plant sciences (Wright et al., 2004; Vile et al., 668 2005; Mauseth, 2006), evolution sciences (Schluessel et al., 2008) and marine ecology 669 (Fuhrman \& Steele, 2008). The comparative analysis of agroecosystems andcomparisons of 670 agroecosystems with natural ecosystems involve the simultaneous analysis of multiple 671 criteria, with evaluation of the extent to which theydisplayspecific system properties. Several 672 approaches have been proposed for this purpose (e.g., Pannel and Glenn, 2000; de Bie, 2000; $673 \mathrm{Xu}$ and Mage, 2001; Lopez-Ridaura et al., 2002; Giampietro, 2003), based largely on 674 concepts formulated more than a decade ago, by authors such as Conway (1987) andMartern 675 (1988). These methods evaluateindicators relatingto the properties of agroecosystems, such as 676 productivity, stability and resilience. These properties are often interdependent and, as pointed 677 out by Marten (1988), they are not universal and must be redefined under each new set of 678 conditions. As discussed above, studies of the local knowledge sustaining various 679 mechanisms of indigenous resilience across contrasting agroecosystems, particularly at the 
680

681

682

683

684

685

686

687

688

689

690

691

692

693

694

695

696

697

698

699

700

701

702

703

704

scale of the landscape and its functionality (e.g., Birman et al., 2010), are also a promising starting point for obtaining information useful for ecological intensification. In the next few paragraphs, we examine briefly some critical issues relating to the choice of indicators in multicriteria evaluations (3.2.1) and identify innovative ways of looking at the relationship between structure and function in agroecosystems.

\subsubsection{Comparative analysis based on multiple indicators}

In practice, the implementation of multicriteria analytical frameworks often involves the selection of a number of indicators (or the use of a list of predetermined indicators) and of reference threshold values for each indicator. The selection of indicators is frequently biased towards the disciplinary standpoint of the observer or highly influenced by certain stakeholders, so 'quality control' methods for evaluating the choice of indicators are necessary. In their examination ofthe choice of indicators in different case studies, Groot and Pacini (2010) argued that multicriteria evaluations should involve the analysis of four main system properties: performance, diversity, coherence and connectedness, which can be approached from four dimensions: physical, ecological, productive and social. Performance relates to functional properties of the agroecosystem, such as capacity, stability and resilience.

Diversity relates to the structural properties sustaining such functions. Indicators of coherence describe the degree of interaction between components or subsystems within an agroecosystem, andconnectedness describes interactions with adjacent systems (i.e., other agroecosystems, urban or natural systems, etc.). When several indicators are considered simultaneously, it may be pertinent to check whether all the relevant criteria pertaining to system performance, diversity, coherence or connectedness are given equal importance. For example, López-Ridaura et al. (2002) and Pacini et al.(2003) used two sets of indicators in two independent evaluations of agroecosystems. Although both methods considered multiple 
criteria pertaining to system sustainability, they weighted thevarious system properties and/or

706 dimensions of sustainability differently.

707

708 In general, comparative analyses based on indicators providea static picture of the status of 709 agroecosystems at one particular point in time, without considering the underlying feedback 710 and system dynamics responsible for bringing the system to its current status and for any 711 subsequent change to that status. Beyond comparing multiple indicators and the tradeoffs 712 between them, the comparative analysis of agroecosystems should aim to distil the 713 relationships between relevant properties; e.g., between performance on the one hand, and 714 diversity, coherence and connectedness on the other. A common denominator ofthe indicators 715 used in multi-criteria evaluations is their interdependence and their dependence on the

716 structural diversity of the agroecosystem. Thisinterdependence results from the co-adaptation 717 of agroecosystem components over time. The structural diversity 718 ofagroecosystems,corresponding to the diversity of system components and their 719 interrelationships, is only functional when organised in a specific way.

\section{$\underline{3.2 .2 \text { Analysing the structure and functioning of agroecosystems }}$}

722 It is often postulated that the ecological intensification of agroecosystems may be achieved 723 through gradual diversification to capitalise on regulatory principles and mechanisms inherent 724 to natural ecosystems (see above and, for example, Altieri, 1999; Gliessman, 2001; Wezel et $725 a l ., 2009)$. Knowledge of the structural diversity of an agroecosystem, however, may not be 726 sufficient to explain its behaviour, and the way in which the diverse components of the system 727 relate to each other should also be known. Moreover, unnecessarily high degrees ofdiversity 728 of system components and flows within systems with poorly organised configurations may 729 lead to redundancy (Kauffman, 1995; Ulanowicz, 2004). Here, we examine some methods for 
studying the diversity and organisation of system components based on the theory of networks

731 that may be used in the comparative analysis of agroecosystems.

732

733 Indicators of networkcomplexity and organisation have beenderived from communication

734 science. They were first used in economics by Leontief $(1951,1966)$, and later introduced into

735 ecology by Hannon (1973). Indicators, such as average mutual information (AMI) and

736 ascendency (A), were proposed by Ulanowicz (1997, 2004) for characterisation of the

737 development capacity (in terms of increased organisation) of ecological systems, and have

738 recently been used in comparative analyses of agroecosystems (Rufino et al., 2009).

739 Thisapproachis known as ecological network analysis, and Rufino et al. (2009)presenteda set

740 of indicators including AMI, A, and Finn's cycling index, for assessment of the diversity and

741 organisation of system components governing $\mathrm{N}$ flows and food self-sufficiency in three

742 smallholder crop-livestock systems from Ethiopia, Kenya and Zimbabwe. Farm systems are

743 conceptualised as networks, with the household and the farming activities represented

744 ascompartments and the $\mathrm{N}$ flows represented as connections between compartments. In this

745 example, indicators assessing network size, activity, cycling, organisation and diversity of the

$746 \mathrm{~N}$ flows were compared with indicators of productivity and household food self-sufficiency.

747 This analysis revealed that although the amounts of $\mathrm{N}$ cycled were small and similarat all

748 sites, resource use efficiency and dependence on external resources differed widely between

749 these apparently 'comparable' agroecosystems. System performance was positively related to

$750 \mathrm{~N}$ flow network size, organisation and $\mathrm{N}$ cycling, consistent with the hypothesis that

751 increasing the organisation of resource cycling within resource-limited agroecosystems may

752 render these systems more adaptable and less vulnerable. 
754 The main hypothesis underlyingthe use of these indicators is that agroecosystems retain the 755 properties of the natural ecosystems for which these indices were derived. Ulanowicz (2004) 756 calculated the value of several indicators of network size and organisation, such as the number 757 of different nodes and flows, their roles and their connectivity, for a number of natural 758 ecosystems and agroecosystems. This exercise revealed wider gaps between these systems in 759 terms of indicators of organisation than for the magnitude of energy matter and information 760 flow within them. In other words, increasing organisation makes it possible to do much more 761 with the same resources, while contributing to system stability. The extent and the manner in 762 which organisation contributes to building resilience in agroecosystems is a fascinating 763 research area that remains largely unexplored. Existing frameworks of thinking about 764 resilience in the field of ecology and nature conservation may also be of interest here (e.g., 765 Walker et al., 2010). An indirect measurement of the organisation of an agroecosystem is its 766 energy and entropy balance. Svirezhev (2000) proposed the use of thermodynamics concepts to assess the sustainability of agroecosystems, based on the principle that an ecosystem in equilibrium with its environment has a certain 'capacity' to absorb anthropogenic stress that is

769 regulated by its capacity to expel entropy back towards the environment (the 'entropy pump').

770 This capacity, which emerges from variousagroecosystem properties, can be used to 771 characterise the status of an agroecosystem with respect to the adjacent natural ecosystem 772 from which it has been derived.

774 Manyof the properties of agroecosystems are often interdependent, together determining 775 thevulnerability and adaptation capacity of these systems in the face of external shocks and 776 stressors (Luers, 2005). Far from being postulates of a new theory, these properties are 777 discussed here as operational, working concepts. We know that the provision of 778 agroecosystem service functions is regulated by the intrinsic properties of these systems, 
thefunctionality of which can be influenced by design. In practical terms, 'design' implies proposing alternative configurations for the organisation of energy, matter and information flows towards, within and from the system in space and time. The examples examined here indicate that, up to a certain critical level, an increase in the diversity of system components and interrelationships confers desirable properties onagroecosystems consistent with the paradigm of ecological intensification. However, these properties manifest themselves as patterns in space and time that become more evident at particular scales and are often described as variability and/or heterogeneity at other scales. Diversity and spatio-temporal variability or heterogeneity are inherent to agroecosystems (Burel \& Baudry, 2003), and may represent constraints to the representation of these systems in prototyping or modelling, which isoften based on modal agroecosystem configurations.

\section{4 - Overall discussion and conclusion}

Wide new avenues seem to be opening up in agronomy to guide ecological intensification. We have tried here to identify new sources of knowledge and methods and to consider their potential role (Figure 1). The analysis, use and optimisation of biological regulation in agroecosystems are the most commonly promoted methods of ecological intensification. This approach frequently involves enlarging the foundations of agronomic knowledgeto cover biotic components of the system and their interactions. This ecological analysis of the whole system is of paramount importance, and further investment in this approach is required.This will involve the expansion of agronomic knowledge through classical avenues of research, involving the generation of data mostlythrough modelling and on-station experiments, and their analysis through simulation studies or statistical hypothesis testing. Our proposed approach is complementary to attempts to increase our understanding of biological regulations in agroecosystems and to use this knowledgefor ecological intensification. Indeed, the 
804 extension of sources of knowledge to natural ecosystems and farmers' knowledge relates

805 mostly tobiological regulation and is fundamentally consistent with the scientific approach to 806 acquiring knowledge about biological regulation in agroecosystems. The extension of sources

807 of knowledge to the results of plant sciencesresearch is more debatable. For example, 808 Vanloqueren andBaret (2009) argued that genetic engineering closes off avenues 809 ofagroecological innovation. However, plant science results are not inevitably linked to a 810 single technological regime. Agronomists, if they were aware of current knowledge in plant 811 sciences, could make use of some of this knowledge to rebalance technological regimes or to 812 construct new ones. The expansion of sources of knowledge will also indirectly promote ways 813 of generating data that are little used at the moment. Most agronomic data are still acquired 814 through on-station trials and modelling. The extension of sources of knowledge to farmers' 815 knowledge and natural ecosystems will highlightalternative methodsof data generation. This 816 will, in turn, incite the development of new data processing methods, such as meta-analysis 817 and comparative studies.

819 The new avenues outlined here will require major methodological investment. Indeed, the 820 extension of sources of knowledge suggested here is far from straightforward. Plant science 821 results must be thoroughly screened by groups of agronomists and plant scientists working 822 together, to identify the most promising results for use in ecological intensification. Three 823 major points should be made:

824 (i) Most plant science knowledge of potential use in agronomy is based on genetic 825 drivers. As gene expression depends on environmental conditions, the use ofplant science 826 data in ecological intensification will require qualification and quantification of the 827 corresponding genotype $\mathrm{x}$ environment interactions, for a range of cropping systems, soils 828 and climatic conditions (see for example Spiertz et al., 2007). 
(ii) All dimensions of cropping system management may benefit from a greater

830 knowledge of plant biologyand soil ecology: crop rotation sequences, soil management,

831 crop management etc.Furthermore, most of the issues raised by ecological intensification

832 can be addressed: yield increase, cut-off forthe use of limited resources through better

833 mineral use efficiency, decrease in pesticide use through the adoption of new crop

834 protection methods, etc.

835 (iii) Our paper is limited to afew examples. To our knowledge, probably due to 836 schism betweenagronomists and plant scientists, no formal attempt to enlarge this list has

837 been made by systematically tracking plant science results of potential use in cropping 838 system design. Such tracking of results and the publication of the findings obtained would $839 \quad$ nonetheless be of considerable interest.

841 The use of knowledge relating to natural ecosystems requires clarification concerning 842 what to study and how, for each of the properties of agroecosystems that ecological 843 intensification aims to improve. This suggests a possible step-wise course of action for 844 agronomists seeking to mimic natural ecosystems:

845 - Selection of the functions agronomists wish to improve (for example, nutrient cycle $846 \quad$ management);

847 - Identification, in natural ecosystems, of the structural characteristics (spatial 848 heterogeneity, diversification of vegetation strata, variability of species in time and $849 \quad$ space, etc.) modifying these functions;

850 - Definition of the qualitative or quantitative relationships linking properties and functions;

$852 \quad-\quad$ Transposition of these functions toagricultural conditions;

$853 \quad-\quad$ Use of these functions for the design ofagroecosystems with specified aims; 

noundesirableproperties.

856 This procedure seems far more complex than simply trying to design agroecosystems "as

857 similar as possible" to natural ecosystems.

859 Farmers' knowledge seems to be extremely valuable, and its use in association with scientific

860 knowledge requires appropriate processing by methods that are not yet well established.

861 Specific methods remain to be adapted from other domains or developed. The first

862 methodological requirement is a more profound analysis of local knowledge to

863 determinewhich processes (ecological or otherwise) should beselected and how they can

864 beused or manipulated. Davis andRuddle (2010) analysed the ways in whichecological

865 knowledge (local, traditional or indigenous) is used and concluded that the same level of

866 scrutiny as for scientific experimental results should be applied before such knowledge is

867 accepted. However, this local knowledge is built within specific 'systems of knowledge'

868 (Davis \& Ruddle, 2010), and thereforecannot be analysed purely in terms of its content

869 relevant to agronomy or ecological science. It must also be analysed from a social point of

870 view (which processes lead to this knowledge? How is it shared, transmitted etc.?). This

871 analysis calls for pluridisciplinary approaches. We also need to design approaches inspired by

872 or directly making use of the argumentation theory and methods developed in the domain of

873 artificial intelligence (Amgoud \& Prade, 2009).

875 The use of meta-analysis methods for ecological intensification benefits from extensive 876 experience in other research areas, and follows guidelines that have proved to be effective.

877 Nevertheless, data acquisition in agronomy has not traditionally been organised with the 878 requirements of subsequent meta-analyses in mind. As a consequence, considerable effort is 
879 required to adapt the methods to existing agronomic data and to establish guidelines for the 880 generation of further data. Finally, comparative studies in agriculture often remain 881 descriptive, and are not always oriented to identify the relationships between agroecosystem 882 structure and functioning - undoubtedly a new challenge for agronomic research.Addressing 883 this aim will require the development of guidelines for site selection, characterisation 884 methods, data processing, etc.

885

886 Finally, each of the five topics outlined will probably require specific organisation within 887 research institutes. They may also induce changes in academic curricula in agronomy, as plant 888 scientists and agronomists currently follow different curricula, with little in the way of shared 889 knowledge, concepts and technical skills.

890

891 Acknowledgement: we thank Alain Bône and Julie Sappa for their skilled assistance. 892

\section{$893 \quad$ Figure captions}

894 Figure 1. Summary of new avenues ofagronomic research for ecological intensification 


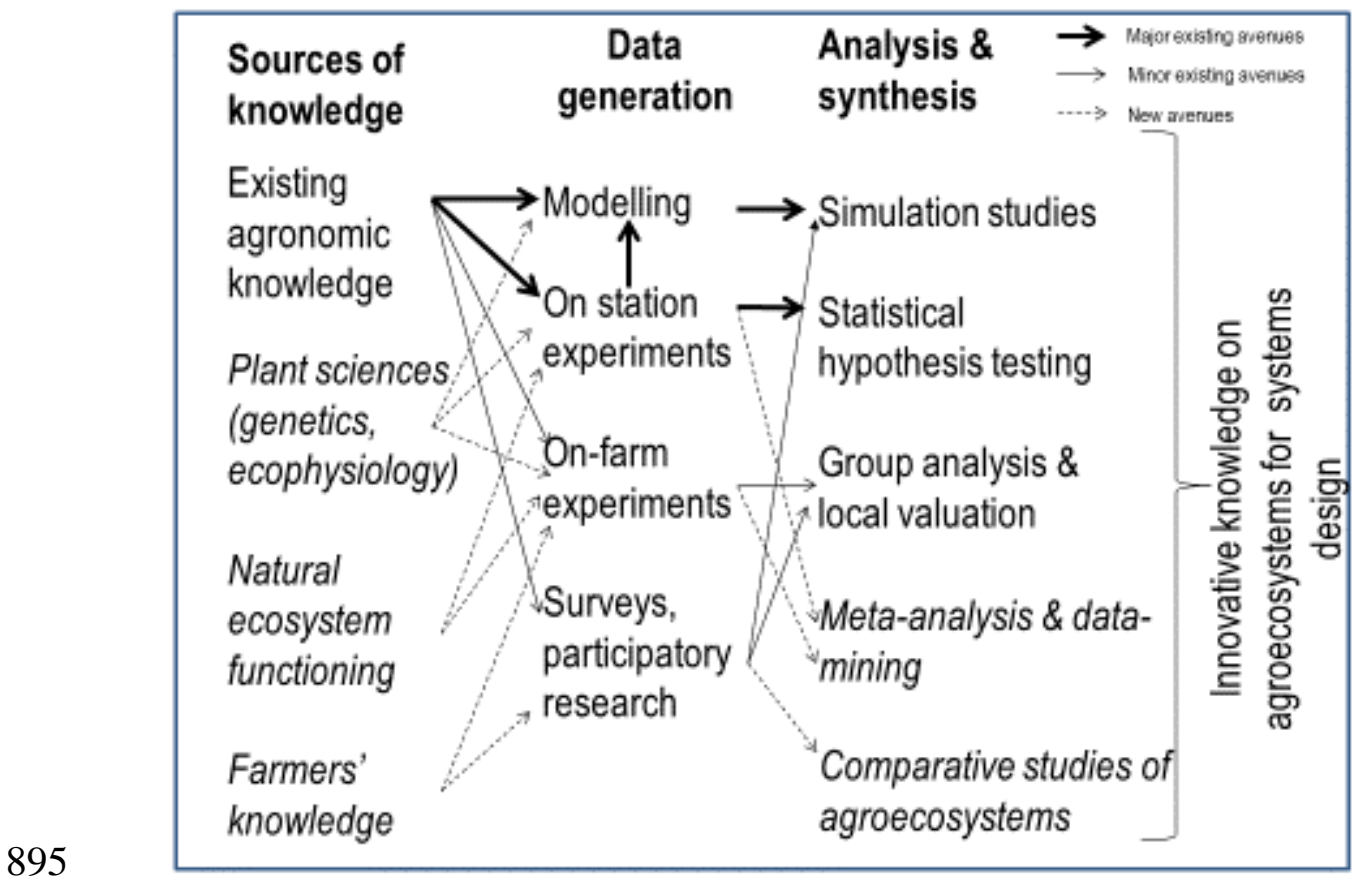

896 
897 Figure 2. A comparison of natural ecosystems, conventional cropping systems and

898 agroecosystems inspired from natural ecosystems, with an emphasis on crop protection

899

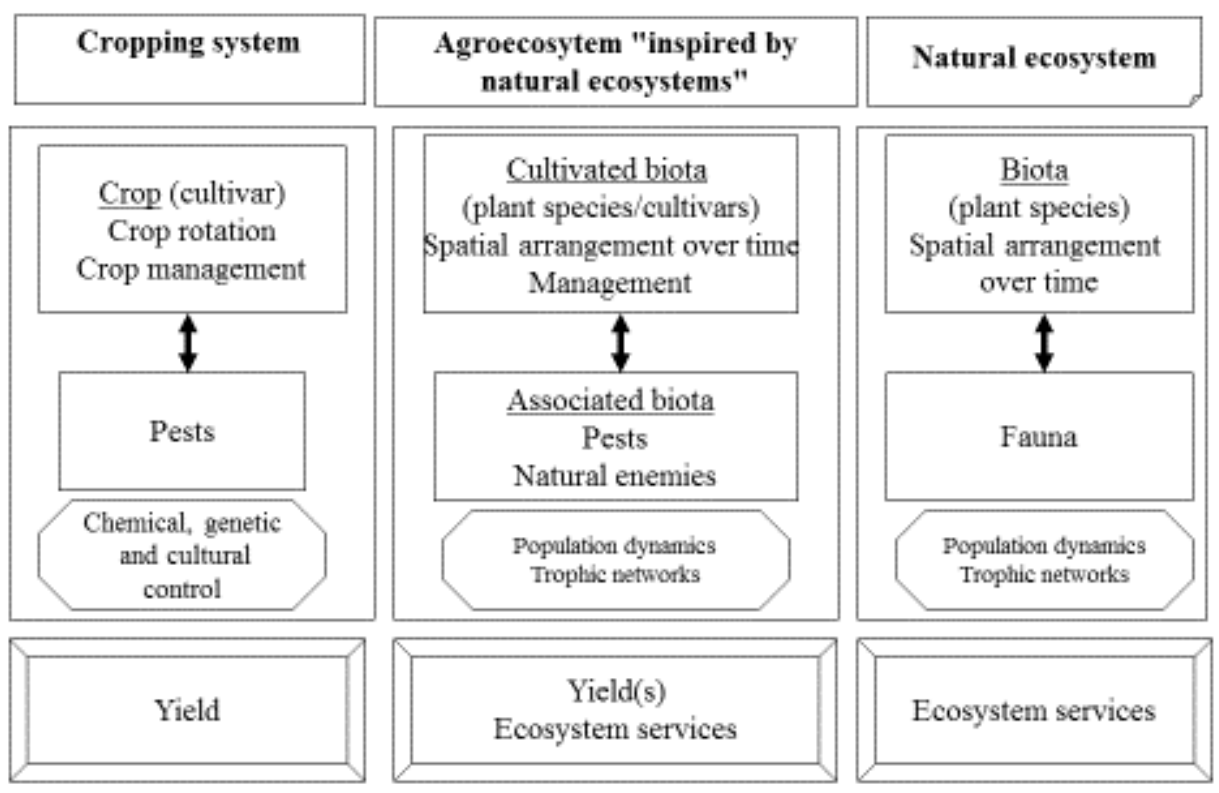

900

901

902 
904

905 Table 1. Examples of recent results fromplant sciences useful in agronomy

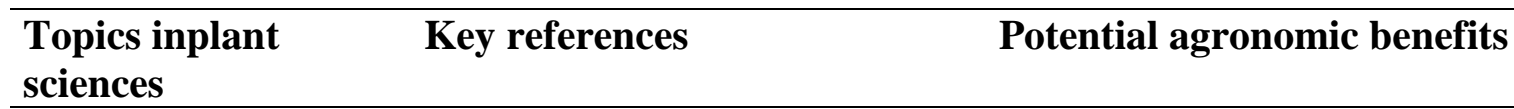

Plant architecture Zhu et al. (2010)

Walter et al. (2009)

Increased radiation interception

dePury\& Farquhar (1997)

Photosynthesis $\quad$ Wang \& $\mathrm{Li}(2008)$

Canopy pattern target for crop

efficiency management

Increase in yield

Identification of genotypes adapted for crop mixture

Improved fertiliser use efficiency

between roots and

Jackson et al. 2008

environment

Role of organic anion Glass (2003)

Improved nitrogen management

exudation

Ryan et al. (2001)

Interaction between Mehboob et al. (2009)

Improved mineral nutrition

roots and soil

organisms

Brussaard et al. (2007)

Role of common
mycorrhizal networks

Micallef et al. (2009)

Improved crop growth

Ryan et al. (2009)

Adaptation of crop management

Sturz and Nowak (2000)

Van der Heijden \& Horton

(2009)

Interaction between

De Bruxelles \& Roberts (2001)

Management of natural defences aerial parts of the for improved resistance to pests plant and environment 
908 Table 2. Examples of farmers' knowledge potentially useful in agronomy

\begin{tabular}{lll} 
Sources of knowledge & Key references & Potential agronomic benefit \\
\hline $\begin{array}{l}\text { Local ecological } \\
\text { knowledge }\end{array}$ & $\begin{array}{l}\text { Chalmers \& } \\
\text { Fabricius (2007) }\end{array}$ & Explaining changes in agricultural systems \\
\hline
\end{tabular}

Traditional farming Singh \& Sureja Design of sustainable farming systems systems (2007)

Abbona et al. Understanding of ecological processes (2007)

Local knowledge and Ballard et al. Assessment of management practices for indicators for assessing (2008) forests

forest management

Farmer's indicators supporting decision

Tchamitchian et al. Indicators with expanded domains of validity making (2006) 


\section{$\underline{\text { References }}$}

911 Abbona, E.A., Sarandón, S.J., Marasas, M.E., Astier, M., 2007. Ecological sustainability evaluation of traditional management in different vineyard systems in Berisso, Argentina. Agric. Ecosyst. Environ. 119, 335-345.

Acosta-Martinez, V., Dowd, S., Sun, Y., Allen, V., 2008. Tag-encoded pyrosequencing analysis of bacterial diversity in a single soil type as affected by management and land use. Soil Biol. Biochem. 40, 2762-2770.

Aerts, R., 1999. Interspecific competition in natural plant communities: mechanisms, tradeoffs and plant-soil feedbacks. J. Exp. Bot. 50, 29-37.

Affholder, F., Jourdain, D., Morize, M., Quang, D.D., Ricome, A., 2008. Ecological intensification in the mountains of Vietnam: constraints to the adoption of cropping systems based on mulches and cover crops. Cah. Agric. 17, 289-296.

Affholder, F., Jourdain, D., Quang, D.D., Tuong, T.P., Morize, M., Ricome, A., 2010. Constraints to farmers' adoption of direct-seeding mulch-based cropping systems: A farm scale modeling approach applied to the mountainous slopes of Vietnam. Agric. Syst. 103, 51-62.

Alsinet, T., Chesñevar, C.I., Godo, L., Simari, G.R., 2008. A logic programming framework for possibilistic argumentation: Formalization and logical properties. Fuzzy Sets Syst. $159,1208-1228$.

Altieri, M.A., 2002. Agroecology: the science of natural resource management for poor farmers in marginal environments. Agric. Ecosyst. Environ. 93, 1-24.

Altieri, M.A., 1999. The ecological role of biodiversity in agroecosystems. Agric. Ecosyst. Environ. 74, 19-31.

Altieri, M.A., 1989. Agroecology - A new research and development paradigm for world agriculture. Agric. Ecosyst. Environ. 27, 37-46. 
Amgoud, L., Kaci, S., 2007. An argumentation framework for merging conflicting knowledge bases. Int. J. Approx. Reason. 45, 321-340.

Amgoud, L., Prade, H., 2009. Using arguments for making and explaining decisions. Artif. Intell. 173, 413-436.

Arnqvist, G., Wooster, D., 1995. Metaanalysis - synthesizing research findings in ecology and evolution. Trends Ecol. Evol. 10, 236-240.

Baars, T., de Vries, A., 1999. Facilitating empirical learning in agriculture — scientific knowledge and practical choices: forging a link between the way of the researcher/extensionist and the way of the farmer, in: Zanoli, R., Krell, R. (Eds.), Landscape Ecology in Agroecosystems ManagementRome (ITA), (REU Technical series, vol. 58), pp. 49-56.

Badgley, C., Moghtader, J., Quintero, E., Zakem, E., Chappell, M.J., Aviles-Vazquez, K., Samulon, A., Perfecto, I., 2007. Organic agriculture and the global food supply. Renewable Agriculture and Food Systems 22, 86-108.

Bais, H.P., Park, S.W., Weir, T.L., Callaway, R.M., Vivanco, J.M., 2004. How plants communicate using the underground information superhighway. Trends Plant Sci. 9, $26-32$.

Bais, H.P., Weir, T.L., Perry, L.G., Gilroy, S., Vivanco, J.M., 2006. The role of root exudates in rhizosphere interations with plants and other organisms. Annu. Rev. Plant Biol. 57, 233-266.

Ballard, H.L., Fernandez-Gimenez, M.E., Sturtevant, V.E., 2008. Integration of local ecological knowledge and conventional science: a study of seven community-based forestry organizations in the USA. Ecol. Soc. 13, art. n. 37 (http://www.ecologyandsociety.org/vol13/iss2/art37/).

Barbottin, A., Makowski, D., Le Bail, M., Jeuffroy, M.-H., Bouchard, C., Barrier, C., 2008. 
Comparison of models and indicators for categorizing soft wheat fields according to their grain protein contents. Eur. J. Agron. 29, 175-183.

Barzman, M.S., Mills, N.J., Thi Thu Cuc, N., 1996. Traditional knowledge and rationale for weaver ant husbandry in the Mekong delta of Vietnam. Agric. Human Values 13, 2-9.

Bench-Capon, T.J.M., Dunne, P.E., 2007. Argumentation in artificial intelligence. Artif. Intell. 171, 619-641.

Bengtsson, J., Ahnström, J., Weibull, A.-C., 2005. The effects of organic agriculture on biodiversity and abundance: a meta-analysis. J. Appl. Ecol. 42, 261-269.

Bergez, J.-E., Colbach, N., Crespo, O., Garcia, F., Jeuffroy, M.-H., Justes, E., Loyce, C., Munier-Jolain, N., Sadok, W., 2010. Designing crop management systems by simulation. Eur. J. Agronomy 32, 3-9.

Berkes, F., 1999. Sacred ecology: traditional ecological knowledge and resource management. Taylor and Francis, Philadelphia, VA (USA).

Bertin, C., Yang, X.H., Weston, L.A., 2003. The role of root exudates and allelochemicals in the rhizosphere. Plant Soil 256, 67-83.

de Bie, C.A.J.M., 2000. Comparative performance analysis of agro-ecosystems ( $\mathrm{PhD}$ thesis). Wageningen University, Wageningen (NLD).

Birman, D., Moraine, M., Tittonell, P., Martin, P., Clouvel, P., 2010.Ecosystem services assessment in complex agricultural landscapes using farmers' perception, in: Proceedings of AGRO2010, The Scientific International Week on Agronomy. Montpellier (FRA).

Bommel, P., Bonaudo, T., Barbosa, T., Bastos da Veiga, J., Vieira Pak, M., Tourrand, J.-F., 2010. The complex relationship between cattle ranching and the forest in Brazilian Amazonia. A multiagent modelling approach. Cah Agrig. 19, 104-111.

Borenstein, M., Hedges, L.V., Higgins, J.P.T., Rothstein, H.R., 2009. Introduction to Meta- 

Analysis. John Wiley and Sons, Chichester (GBR).

986 Boss, P.K., Bastow, R.M., Mylne, J.S., Dean, C., 2004. Multiple pathways in the decision to flower: Enabling, promoting, and resetting. Plant Cell 16, S18-S31. Bowen, G.D., Rovira, A.D., 1999. The rhizosphere and its management to improve plant growth, in: Advances in Agronomy, (vol. 66), pp. 1-102.

Brookfield, H., Parsons, H., Brookfield, M., 2003. Agrodiversity: Learning from farmers across the world. United Nation University Press, New-York, NY (USA).

Brussaard L., de Ruiter P.C., Brown G.G., 2007. Soil biodiversity for agricultural sustainability. Agric. Ecosyst; Env., 121(3), 233-244.

de Bruxelles, G.L., Roberts, M.R., 2001. Signals regulating multiple responses to wounding and herbivores. Crit. Rev. Plant Sci. 20, 487-521.

Burel, F., Baudry, J., 2003. Landscape Ecology: Concepts, Methods and Applications. Science Publishers, Inc. Enfield, NH, USA.

Cardinale, B.J., Srivastava, D.S., Duffy, J.E., Wright, J.P., Downing, A.L., Sankaran, M., Jouseau, C., 2006. Effects of biodiversity on the functioning of trophic groups and ecosystems. Nature 443, 989-992.

Cassman, K.G., 1999. Ecological intensification of cereal production systems: yield potential, soil quality, and precision agriculture. Proc Natl Acad Sci USA 96, 5952-5959.

Chalmers, N., Fabricius, C., 2007. Expert and generalist local knowledge about land-cover change on South Africa's wild coast: can local ecological knowledge add value to science? Ecol. Soc. 12, art. n. 10 (http://www.ecologyandsociety.org/vol12/iss1/art10/).

Chevassus au Louis, B., Griffon, M., 2008. La nouvelle modernité: une agriculture productive à haute valeur écologique, in: Déméter : Économie et Stratégies Agricoles, (vol. 14), pp. $7-48$. 
1010 Chikowo, R., Corbeels, M., Mapfumo, P., Tittonell, P., Vanlauwe, B., Giller, K.E., 2010. Benefits of integrated soil fertility and water management in semi-arid West Africa: an example study in Burkina Faso. Nutrient Cycl. AgroEcosyst. 88, 59-77.

1013 Conway, G.R., 1987. The properties of agroecosystems. Agric. Syst. 24, 95-117.

1014 Cornelissen, A.M.G., van den Berg, J., Koops, W.J., Kaymak, U., 2003. Elicitation of expert 1015 knowledge for fuzzy evaluation of agricultural production systems. Agric. Ecosyst. $1016 \quad$ Environ. 95, 1-18.

1017 Davis, A., Ruddle, K., 2010. Constructing confidence: rational skepticism and systematic 1018 enquiry in local ecological knowledge research. Ecol. Appl. 20, 880-894.

1019 Dawson, T., Fry, R., 1998. Agriculture in nature's image. Trends Ecol. Evol. 13, 50-51.

1020 Debaeke, P., Munier-Jolain, N., Bertrand, M., Guichard, L., Nolot, J.-M., Faloya, V., Saulas, 1021 P., 2009. Iterative design and evaluation of rule-based cropping systems: methodology 1022 and case studies. A review. Agron. Sustain. Dev. 29, 73-86.

1023 dePury D.G.G.,\& Farquhar G.D., 1997. Simple scaling of photosynthesis from leaves to 1024 canopies without the errors of big-leaf models. Plant Cell Env. 20, 537-557

1025 Doré T., Clermont-Dauphin C., Crozat Y., David C., Jeuffroy M.H., Loyce C., Makowski D., 1026 Malézieux E., Meynard J.M., Valantin-Morison M., 2008. Methodological progress in 1027

1029 Dudareva, N., Pichersky, E., 2008. Metabolic engineering of plant volatiles. Curr. Opin.

$1030 \quad$ Biotechnol. 19, 181-189.

1031 Egger, K., 1986. Ecological intensification. Soil conservation and improvement of tropical 1032 soils by pastoral agroforestry systems. Collection Documents Systèmes Agraires 6, $1033 \quad 129-135$.

1034 Ewel, J., 1999. Natural systems as models for the design of sustainable systems of land use. 
FAO, 2009. Glossary on organic agriculture. FAO, Rome (ITA).

1037 Fortunel, C., Garnier, E., Joffre, R., Kazakou, E., Quested, H., Grigulis, K., Lavorel, S., Ansquer, P., Castro, H., Cruz, P., Dolezal, J., Eriksson, O., Freitas, H., Golodets, C., Jouany, C., Kigel, J., Kleyer, M., Lehsten, V., Leps, J., Meier, T., Pakeman, R., Papadimitriou, M., Papanastasis, V.P., Quetier, F., Robson, M., Sternberg, M., Theau, J.-P., Thebault, A., Zarovali, M., 2009. Leaf traits capture the effects of land use changes and climate on litter decomposability of grasslands across Europe. Ecology $90,598-611$.

Friedman, D.B., Kanwat, C.P., Headrick, M.L., Patterson, N.J., Neely, J.C., Smith, L.U., 2007. Importance of prudent antibiotic use on dairy farms in South Carolina: A pilot project on farmers' knowledge, attitudes and practices. Zoonoses Public Health 54, 366-375.

Fuhrman, J.A., Steele, J.A., 2008. Community structure of marine bacterioplankton: patterns, networks, and relationships to function. Aquat. Microb. Ecol. 53, 69-81.

1050 Fukai, S., 1993. Intercropping - bases of productivity - introduction. Field Crops Res. 34, 239-245.

1052 Funes-Monzote, F.R., Monzote, M., Lantinga, E.A., van Keulen, H., 2009. Conversion of 1053 specialised dairy farming systems into sustainable mixed farming systems in Cuba. Environ. Dev. Sustain. 11, 765--783.

Galloway, J.N., Townsend, A.R., Erisman, J.W., Bekunda, M., Cai, Z., Freney, J.R., Martinelli, L.A., Seitzinger, S.P., Sutton, M.A., 2008. Transformation of the nitrogen cycle: Recent trends, questions, and potential solutions. Science 320, 889-892. 
PA: Swets \& Zeitlinger.

1061 Glass, A.D.M., 2003. Nitrogen use efficiency of crop plants: Physiological constraints upon nitrogen absorption. Crit. Rev. Plant Sci. 22, 453-470.

1063 Gliessman, S.R., 2007. Agroecology: the Ecology of Food Systems (2nd Edition). CRC Press, 1064 Boca Raton, FL (USA).

1065 Gliessman, S.R., 2001. Agroecology: Ecological Processes in Sustainable Agriculture. Lewis 1066 Publisher, Boca Raton, FL (USA).

1067 Grace, D., Randolph, T., Affognon, H., Dramane, D., Diall, O., Clausen, P.-H., 2009. Characterisation and validation of farmers' knowledge and practice of cattle trypanosomosis management in the cotton zone of West Africa. Acta Trop. 111, 137-

1070 143.

1071 Groot, J.C.J., Pacini, G.C., 2010.Evaluation of indicators sets using a polyocular perspective 1072 on agroecosystems, in: Dogliotti, S., Rossing, W.A.H., Cittadini, E., Albín, A. (Eds.), Proceedings of the International Congress on Co-innovation in Sustainable Livelihood Systems. Lavalleja, Uruguay.

Grossman, A., Takahashi, H., 2001. Macronutrient utilization by photosynthetic eukaryotes and the fabric of interactions. Annu. Rev. Plant Physiol. Plant Mol. Biol. 52, 163-210.

Grossman, J.M., 2003. Exploring farmer knowledge of soil processes in organic coffee systems of Chiapas, Mexico. Geoderma 111, 267-287.

1079 Gunderson, L.H., Holling,C.S., (Eds.), 2002. Panarchy: Understanding Transformations in 1080 Human and Natural Systems. Island Press, Washington, p. DC.

1081 Hannon, B., 1973. The structure of ecosystems. J. Theor. Biol. 41, 535-546.

1082 Hatfield C.B., 1997. Oil back on the global agenda. Nature, 387, 121.

1083 He, X.H., Critchley, C., Bledsoe, C., 2003. Nitrogen transfer within and between plants through common mycorrhizal networks (CMNs). Crit. Rev. Plant Sci. 22, 531-567. 
van der Heijden, M.G.A., Horton, T.R., 2009. Socialism in soil? The importance of mycorrhizal fungal networks for facilitation in natural ecosystems. J. Ecol. 97, 11391150.

Henderson, J., 2010. Expert and lay knowledge: a sociological perspective. Nutrition \& Dietetics 67, 4-5.

Holling, C.S., 1973. Resilience and stability of ecological systems. Annu. Rev. Ecol. Syst. 4, $1-23$.

Hooper, D.U., Chapin, F.S., Ewel, J.J., Hector, A., Inchausti, P., Lavorel, S., Lawton, J.H., Lodge, D.M., Loreau, M., Naeem, S., Schmid, B., Setala, H., Symstad, A.J., Vandermeer, J., Wardle, D.A., 2005. Effects of biodiversity on ecosystem functioning: A consensus of current knowledge. Ecol Monogr 75, 3-35.

Hubert, B., Rosegrant, M., van Boekel, M.A.J.S., Ortiz, R., 2010. The future of food: scenarios for 2050. Crop Sci. 50, S33-S50.

Hughes, G., Madden, L.V., 2002. Some methods for eliciting expert knowledge of plant disease epidemics and their application in cluster sampling for disease. Crop Prot. 21, $203-215$.

Jackson, L.E., Burger, M., Cavagnaro, T.R., 2008. Roots, nitrogen transformations, and ecosystem services. Annu. Rev. Plant Biol. 59, 341-363.

Jackson, W., 2002. Natural systems agriculture: a truly radical alternative. Agric. Ecosyst. Environ. 88, 111-117.

Jackson, W., Jackson, L.L., 1999. Developing high seed yielding perennial polycultures as a mimic of mid-grass prairie, in: Lefroy, E.C., Hobbs, R.J., O'Connor, M.H., Pate, J.S. (Eds.), Agriculture as a Mimic of Natural Ecosystems. Kluwer Academic Publishing, Dordrecht (NLD), (Current Plant Science and Biotechnology in Agriculture, vol. 37), pp. 1-38. 
Jones, P.G., Thornton, P.K., 2003. The potential impacts of climate change on maize production in Africa and Latin-America in 2055. Glob. Environ. Change 13, 51-59.

Kauffman, S., 1995. At Home in the Universe: the Search for Laws of Self-Organization and Complexity. Oxford University Press, 321 p.

Kessler, A., Baldwin, I.T., 2002. Plant responses to insect herbivory: The emerging molecular analysis. Annu. Rev. Plant Biol. 53, 299-328.

Kiers, E.T., Denison, R.F., 2008. Sanctions, cooperation, and the stability of plant-rhizosphere mutualisms. Annu. Rev. Ecol. Evol. Syst. 39, 215-236.

Lançon, J., Wery, J., Rapidel, B., Angokaye, M., Gerardeaux, E., Gaborel, C., Ballo, D., Fadegnon, B., 2007. An improved methodology for integrated crop management systems. Agron. Sustain. Dev. 27, 101-110.

Le Bot, J., Bénard, C., Robin, C., Bourgaud, F., Adamowicz, S., 2009. The `trade-off' between synthesis of primary and secondary compounds in young tomato leaves is altered by nitrate nutrition: experimental evidence and model consistency. J. Exp. Bot. $60,4301-4314$.

Lefroy, E.C., Hobbs, R.J., O'Connor, M.H., Pate, J.S., 1999. Agriculture as a mimic of natural ecosystems. Kluwer Academic Publishing, Dordrecht (NLD).

Lemanceau, P., Expert, D., Gaymard, F., Bakker, P.A.H.M., Briat, J.-F., 2009. Role of Iron in Plant-Microbe Interactions, in: Plant Innate Immunity, (Advances in Botanical Research, vol. 51), pp. 491-549.

Leontief, W.W., 1966. Input-Output Economics. Oxford University Press, New York, USA. Leontieff, W.W., 1951. The Structure of the American Economy, 1919-1939: an Empirical Application of Equilibrium Analysis. Oxford University Press.

Ley, T., Kump, B., Albert, D., 2010. A methodology for eliciting, modelling, and evaluating expert knowledge for an adaptive work-integrated learning system. Int. J. Human- 
1136 Li, H., Shen, J., Zhang, F., Clairotte, M., Drevon, J.J., Le Cadre, E., Hinsinger, P., 2008. Dynamics of phosphorus fractions in the rhizosphere of common bean (Phaseolus vulgaris L.) and durum wheat (Triticum turgidum durum L.) grown in monocropping and intercropping systems. Plant Soil 312, 139-150.

Long A.J., Nair P.K.R., 1999. Trees outside forests: agro-, community, and urban forestry. New Forests, 17(1-3), 145-174.

Lough, T.J., Lucas, W.J., 2006. Integrative plant biology: Role of phloem long-distance macromolecular trafficking. Annu. Rev. Plant Biol. 57, 203-232.

López-Ridaura, S., Masera, O., Astier, M., 2002. Evaluating the sustainability of complex socio-environmental systems. The MESMIS framework. Ecological Indicators 2, 135148.

Luers, A.L., 2005. The surface of vulnerability: An analytical framework for examining environmental change. Glob. Environ. Change-Human Policy Dimens. 15, 214-223.

Main, A.R., 1999. How much biodiversity is enough? Agrofor. Syst. 45, $23-41$.

Makowski, D., Tichit, M., Guichard, L., van Keulen, H., Beaudoin, N., 2009. Measuring the accuracy of agro-environmental indicators. J. Environ. Manage. 90, S139-S146.

Malézieux, E., Crozat, Y., Dupraz, C., Laurans, M., Makowski, D., Ozier-Lafontaine, H., Rapidel, B., de Tourdonnet, S., Valantin-Morison, M., 2009. Mixing plant species in cropping systems: concepts, tools and models. A review. Agron. Sustain. Dev. 29, 4362.

Malézieux, E., 2011. Designing cropping systems from Nature. Agron. Sustain. Dev.

DOI: $10.1007 / \mathrm{s} 13593-011-0027-\mathrm{z}$

Matson, P.A., Parton, W.J., Power, A.G., Swift, M.J., 1997. Agricultural intensification and ecosystem properties. Science 277, 504-509. 
1162 Maurel, C., Verdoucq, L., Luu, D.-T., Santoni, V., 2008. Plant aquaporins: Membrane 1163 channels with multiple integrated functions. Annu. Rev. Plant Biol. 59, 595-624.

1164 Mauseth, J.D., 2006. Structure-function relationships in highly modified shoots of Cactaceae. $1165 \quad$ Ann. Bot. 98, 901-926.

1166 McNeely, J.A., Scherr, S.J., 2003. Ecoagriculture, Strategies to Feed the World and Save 1167 Wild Biodiversity. Island Press, Washington, DC (USA).

1168 McSteen, P., Leyser, O., 2005. Shoot branching. Annu. Rev. Plant Biol. 56, 353-374.

1169 Médiène, S., Valantin-Morison, M., Sarthou, J.-P., de Tourdonnet, S., Gosme, M., Bertrand, 1170 M., Roger-Estrade, J., Aubertot, J.-N., Rusch, A., Motisi, N., Pelosi, C., Doré, T., 1171 2011. Agroecosystem management and biotic interactions. A review. Agron. Sustain. 1172 Dev. (in press)

1173 Mehboob, I., Naveed, M., Zahir, Z.A., 2009. Rhizobial association with non-legumes: 1174 mechanisms and applications. Crit. Rev. Plant Sci. 28, 432-456.

1175 Meinzen-Dick, R., DiGregorio, M., McCarthy, N., 2004. Methods for studying collective 1176 action in rural development. Agric. Syst. 82, 197-214.

1177 Micallef, S.A., Shiaris, M.P., Colon-Carmona, A., 2009. Influence of Arabidopsis thaliana 1178 accessions on rhizobacterial communities and natural variation in root exudates. J. $1179 \quad$ Exp. Bot. 60, 1729-1742.

1180 Michon, G., de Foresta, H., Levang, P., Verdeaux, F., 2007. Domestic forests: A new 1181 paradigm for integrating local communities' forestry into tropical forest science. Ecol. 1182 Soc. 12, art. n. 1 (http://www.ecologyandsociety.org/vol12/iss2/art1/).

1183 Michon, G., de Foresta, H., Levang, P., 1995. Strategies agroforestières et développement 1184 durable : les agroforêts à Damar de Sumatra. Nat. Sci. Soc. 3, 207-221.

1185 Miguez, F.E., Bollero, G.A., 2005. Review of corn yield response under winter cover 1186 cropping systems using meta-analytic methods. Crop Sci. 45, 2318-2329. 
Miguez, F.E., Villamil, M.B., Long, S.P., Bollero, G.A., 2008. Meta-analysis of the effects of management factors on Miscanthus x giganteus growth and biomass production. Agric. For. Meteorol. 148, 1280-1292.

Mikolasek, O., Khuyen, T.D., Medoc, J.-M., Porphyre, V., 2009. The ecological intensification of an integrated fish farming model: Recycling pig effluents from farms in Thai Binh province (North Vietnam). Cah. Agric. 18, 235-241.

Monod, H., Naud, C., Makowski, D., 2006. Uncertainty and sensitivity analysis for crop models, in: Wallach, D., Makowski, D., Jones, J.W. (Eds.), Working with dynamic crop models. Elsevier Edition, pp. 55-100.

Monteith, J.L., 1977. Climate and efficiency of crop production in Britain. Philos. Trans. R. Soc. London B 281, 277-284.

Nair, P.K.R. 2001. Do tropical homegardens elude science, or is it the other way around? Agrofor. Syst. 53, 239-245.

Navarrete, M., Jeannequin, B., Sebillotte, M., 1997. Vigour of greenhouse tomato plants (Lycopersicon esculentum Mill.): analysis of the criteria used by growers and search for objective criteria. J. Hortic. Sci. 72, 821-829.

van Noordwijk, M., Ong, C.K., 1999. Can the ecosystem mimic hypotheses be applied to farms in African savannahs? Agrofor. Syst. 45, 131-158.

Normand, S.-L.T., 1999. Tutorial in biostatistics. Meta-analysis: formulating, evaluating, combining, and reporting. Stat. Med. 18, 321-359.

Okoba, B.O., de Graaff, J., 2005. Farmers' knowledge and perceptions of soil erosion and conservation measures in the Central Highlands, Kenya. Land Degrad. Devel. 16, $475-487$.

Pacini, C., Wossink, A., Giesen, G., Vazzana, C., \& Huirne, R., 2003. Evaluation of sustainability of organic, integrated and conventional farming systems: a farm and 
field-scale analysis. Agriculture, Ecosystems and Environment, 95, 273-288.

1213 Pannell, DJ., Glenn, N.A., 2000. A framework for the economic evaluation and selection of sustainability indicators in agriculture. Ecological Economics 33, 135-149.

1215 Pietikäinen, A., Kytöviita, M.-M., 2007. Defoliation changes mycorrhizal benefit and 1216 competitive interactions between seedlings and adult plants. J. Ecol. 95, 639-647.

1217 Prior, L., 2003. Belief, knowledge and expertise: the emergence of the lay expert in medical 1218 sociology. Sociol. Health. Ill. 25, 41-57.

1219 Reed, M.S., Dougill, A.J., Taylor, M.J., 2007. Integrating local and scientific knowledge for adaptation to land degradation: Kalahari rangeland management options. Land Degrad. Devel. 18, 249-268.

Reis, V.M., Baldani, J.I., Baldani, V.L.D., Dobereiner, J., 2000. Biological dinitrogen fixation in gramineae and palm trees. Crit. Rev. Plant Sci. 19, 227-247.

Roberts, J.A., Elliott, K.A., Gonzalez-Carranza, Z.H., 2002. Abscission,dehiscence, and other cell separation processes. Annu. Rev. Plant Biol. 53, 131-158.

Rochette, P., Janzen, H.H., 2005. Towards a revised coefficient for estimating $\mathrm{N}_{2} \mathrm{O}$ emissions from legumes. Nutrient Cycl. AgroEcosyst. 73, 171-179.

Rolland, M.-N., Gabrielle, B., Laville, P., Serça, D., Cortinovis, J., Larmanou, E., Lehuger, S., Cellier, P., 2008. Modeling of nitric oxide emissions from temperate agricultural soils. Nutrient Cycl. AgroEcosyst. 80, 75-93.

1231 Rosenberg, M.S., Garrett, K.A., Su, Z., Bowden, R.L., 2004. Meta-analysis in plant pathology: Synthesizing research results. Phytopathology 94, 1013-1017.

Rossing, W.A.H., Meynard, J.-M., van Ittersum, M.K., 1997. Model-based explorations to support development of sustainable farming systems: case studies from France and the Netherlands. Eur. J. Agron. 7, 271-283.

Rufino, M.C., Tittonell, P., Reidsma, P., López-Ridaura, S., Hengsdijk, H., Giller, K.E., 
Verhagen, A., 2009. Network analysis of $\mathrm{N}$ flows and food self-sufficiency-a comparative study of crop-livestock systems of the highlands of East and southern Africa. Nutrient Cycl. AgroEcosyst. 85, 169-186.

Ryan, P.R., Delhaize, E., Jones, D.L., 2001. Function and mechanism of organic anion exudation from plant roots. Annu. Rev. Plant Physiol. Plant Mol. Biol. 52, 527-560.

Ryan, P.R., Dessaux, Y., Thomashow, L.S., Weller, D.M., 2009. Rhizosphere engineering and management for sustainable agriculture. Plant Soil 321, 363-383.

Saito, K., Linquist, B., Keobualapha, B., Shiraiwa, T., Horie, T., 2006. Farmers' knowledge of soils in relation to cropping practices: A case study of farmers in upland rice based slash-and-burn systems of northern Laos. Geoderma 136, 64-74.

Sanchez, P.A. 1995. Science in agroforestry. Agrofor. Syst. 30, 5-55.

Sanon, A., Andrianjaka, Z.N., Prin, Y., Bally, R., Thioulouse, J., Comte, G., Duponnois, R., 2009. Rhizosphere microbiota interfers with plant-plant interactions. Plant Soil 321, 259-278.

Sauvant, D., Schmidely, P., Daudin, J.J., St-Pierre, N.R., 2008. Meta-analyses of experimental data in animal nutrition. Animal 2, 1203-1214.

Schluessel, V., Bennett, M.B., Bleckmann, H., Blomberg, S., Collin, S.R., 2008.

Morphometric and ultrastructural comparison of the olfactory system in elasmobranchs: the significance of structure-function relationships based on phylogeny and ecology. J. Morphol. 269, 1365-1386.

Schroth, G., da Fonseca, G.A.B., Harvey, C.A., Gascon, C., Vasconcelos, H.L., Izac, A-M.. N., 2004. Agroforestry and biodiversity conservation in tropical landscapes. Island Press, Washington, DC (USA).

Schroth, G., Lehmann, J., Rodrigues, M.R.L., Barros, E., Macedo, J.L.V. 2001. Plant-soil interactions in multistrata agroforestry in the humid tropics. Agrofor. Syst. 53, 85-102. 
1262 Schulte, R.P.O., Lantinga, E.A., Struik, P.C., 2003. Analysis of the production stability of mixed grasslands I: A conceptual framework for the qualification of production stability in grassland ecosystems. Ecol. Model. 159, 43-69.

Singh, R.K., Sureja, A.K., 2008. Indigenous knowledge and sustainable agricultural resources management under rainfed agro-ecosystem. Indian J. Tradit. Knowl. 7, 642-654.

Sinzogan, A.A.C., van Huis, A., Kossou, D.K., Jiggins, J., Vodouhe, S., 2004. Farmers' knowledge and perception of cotton pests and pest control practices in Benin: results of a diagnostic study. NJAS-Wagen. J. Life Sci. 52, 285-303.

de Soto, H., 2000. The Mystery of Capital: Why Capitalism Triumphs in the West and Fails Everywhere Else. Basic Books, New-York, NY (USA).

Spiertz, J.H.J., 2010. Nitrogen, sustainable agriculture and food security. A review. Agron. Sustain. Dev. 30, 43-55.

Spiertz, J.H.J., Struik, P.C, van Laar, H.H., 2007. Scale and Complexity in Plant Systems Research: Gene-Plant-Crop Relations. Springer, 332 p.

Spitters C.J.T., 1986. Separating the diffuse and direct component of global radiation and its implications for modeling canopy photosynthesis. 1. Calculation of canopy

Spitters C.J.T., Toussaint H.A.J.M., Goudriaan J., 1986. Separating the diffuse and direct component of global radiation and its implications for modeling canopy photosynthesis. 1. Components of incoming radiation. Agric. Forest Meteor., 38(1-3), 217-229.

1284

Sprent, J.I., Sutherland, J.M., Defaria, S.M., 1987. Some aspects of the biology of nitrogenfixing organisms. Philos. Trans. R. Soc. Lond. Ser. B-Biol. Sci. 317, 111-129. functional genomics of legume nodulation. Curr. Opin. Plant Biol. 9, 110-121. 
Steiner, K.G., 1998. Using farmers' knowledge of soils in making research results more relevant to field practice: Experiences from Rwanda. Agric. Ecosyst. Environ. 69, 191200.

Sturz, A.V., Nowak, J., 2000. Endophytic communities of rhizobacteria and the strategies required to create yield enhancing associations with crops. Appl. Soil Ecol. 15, 183190.

Sutton, A.J., Abrams, K.R., Jones, D.R., Sheldon, T.A., Song, F., 2000. Methods for metaanalysis in medical research. John Wiley, London (BGR).

Svirezhev, Y.M., 2000. Thermodynamics and ecology. Ecol. Model. 132, 11-22.

Swinton, S.M., 2007. Slash-and-burn agriculture: The search for alternatives. Econ. Dev. Cult. Change 56, 234-236.

Tardieu F., Tuberosa R., 2010. Dissection and modeling of abiotic stress tolerance in plants. Current Opinion in Plant Biology, 13(2), 206-212

Tchamitchian, M., Martin-Clouaire, R., Lagier, J., Jeannequin, B., Mercier, S., 2006. Serriste: A daily set point determination software for glasshouse tomato production. Comput. Electron. Agric. 50, 25-47.

Tittonell, P., 2007. Msimu wa Kupanda: targeting resources within diverse, heterogenous and dynamic farming systems of East Africa ( $\mathrm{PhD}$ thesis). Wageningen University, Wageningen (NLD).

Tittonell, P., van Wijk, M.T., Herrero, M., Rufino, M.C., de Ridder, N., Giller, K.E., 2009. Beyond resource constraints - Exploring the biophysical feasibility of options for the intensification of smallholder crop-livestock systems in Vihiga district, Kenya. Agric. Syst. 101, 1-19.

Torquebiau, E., 2007. L'agroforesterie : des arbres et des champs. L'Harmattan, Paris (FRA). Trenbath, B.R., 1993. Intercropping for the management of pests and diseases. Field Crops 
Res. 34, 381-405.

1313 Ulanowicz, R.E., 2004. Quantitative methods for ecological network analysis. Comput. Biol. Chem. 28, 321-339.

Ulanowicz, R.E., 1997. Ecology, the Ascendent Perspective. Columbia University Press, New-York, NY (USA).

Vandemeer, J.H., 2003. Tropical Agroecosystems. CRC Press, Boca Raton, FL (USA).

Vanloqueren G., Baret P., 2009. How agricultural research systems shape a technological regime that develops genetic engineering but locks out agroecological innovations. Research Policy, 38(6), 971-983.

Vereijken, P., 1997. A methodical way of prototyping integrated and ecological arable farming systems (I/EAFS) in interaction with pilot farms. Eur. J. Agron. 7, 235-250.

Vile, D., Garnier, E., Shipley, B., Laurent, G., Navas, M.L., Roumet, C., Lavorel, S., Diaz, S., Hodgson, J.G., Lloret, F., Midgley, G.F., Poorter, H., Rutherford, M.C., Wilson, P.J., Wright, I.J., 2005. Specific leaf area and dry matter content estimate thickness in laminar leaves. Ann. Bot. 96, 1129-1136.

Walker B., Sayer J., Andrew N.L, Campbell B., 2010. Should enhanced resilience be anobjective of natural resource management research for developing countries? Crop Science, 50(2), S10-S19.

Wang, Y., Li, J., 2008. Molecular basis of plant architecture. Annu. Rev. Plant Biol. 59, 253279.

Welbaum, G.E., Sturz, A.V., Dong, Z.M., Nowak, J., 2004. Managing soil microorganisms to improve productivity of agro-ecosystems. Crit. Rev. Plant Sci. 23, 175-193.

Wezel, A., Bellon, S., Doré, T., Francis, C., Vallod, D., David, C., 2009. Agroecology as a science, a movement and a practice. A review. Agron. Sustain. Dev. 29, 503-515.

1336 Wissuwa, M., Mazzola, M., Picard, C., 2009. Novel approaches in plant breeding for 

rhizosphere-related traits. Plant Soil 321, 409-430.

Witt, C., Fairhurst, T.H., Griffiths, W., 2006. The need to increase profitability in oil palm plantations: matching crop and nutrient management principles with evolving strategies. The Planter 82, 377-403.

Wright, I.J., Reich, P.B., Westoby, M., Ackerly, D.D., Baruch, Z., Bongers, F., CavenderBares, J., Chapin, T., Cornelissen, J.H.C., Diemer, M., Flexas, J., Garnier, E., Groom, P.K., Gulias, J., Hikosaka, K., Lamont, B.B., Lee, T., Lee, W., Lusk, C., Midgley, J.J., Navas, M. L .and Niinemets, U., Oleksyn, J., Osada, N., Poorter, H., Poot, P., Prior, L., Pyankov, V.I., Roumet, C., Thomas, S.C., Tjoelker, M.G .and Veneklaas, E. .a.V.R., 2004. The worldwide leaf economics spectrum. Nature 428, 821-827.

Xu, W., Mage, J.A., 2001. A review of concepts and criteria for assessing agroecosystem health including a preliminary case study of southern Ontario. Agric. Ecosyst. Environ. 83, 215-233.

Zhang W., Ricketts T.H., Kremen C., Carney K.,Swinton S.M., 2007. Ecosystem services and dis-services to agriculture. Ecological Economics, 64, $253-260$.

Zhang L., van der Werf W., Bastiaans L., Zhang S., Li B., Spiertz J.H.J., 2008. Light interception and utilization in relay intercrops of wheat and cotton. Field Crops Res. $107,29-42$.

Zhu, X.-G., Long, S.P., Ort, D.R., 2010. Improving photosynthetic efficiency for greater yield, in: Annual Review of Plant Biology, (vol. 61), pp. 235-261. 